MARINA V. N. WHITMAN

University of Pittsburgh

\title{
The Current and Future Role of the Dollar: How Much Symmetry?
}

ON AUGUST 15, 1971, the postwar international monetary system established in 1944 at Bretton Woods was brought to an end by the United States' formal termination of an undertaking that had in fact been largely inoperative for some time: its commitment under the Articles of Agreement of the International Monetary Fund to maintain the parity of the dollar by converting dollar balances held by foreign official institutions into gold at a fixed price on demand. Roughly a year later, at the September 1972 annual meeting of the Board of Governors of the International Monetary Fund, the Secretary of the Treasury put forth a proposal for a reformed international monetary system. In place of a system in which the dollar occupied a unique position, the U.S. proposal envisaged one characterized by far greater symmetry among all currencies. Such symmetry, or legal equality of rights and responsibilities, was also envisioned at Bretton Woods, but in practice the system functioned very differently indeed. A careful survey of recent developments suggests that the quest for symmetry is likely to prove as chimerical today as it did thirty years ago, and that in a viable international monetary system the dollar and the United States are almost certain to continue to play special roles. 


\section{Achievement of Consistency in External Policy Targets}

The issue of symmetry versus asymmetry lies at the heart of ensuring consistency in the international monetary system. In a world of $n$ interdependent countries, only $n-1$ external policies (be they exchange rate policies, reserve targets, or whatever) can be independently determined. If each of the $n$ countries tries to set its policy independently, these policies are almost certain to be inconsistent. The result may very well be a negativesum game, in which the countries end up collectively worse off than they were initially.

Conceptually, the consistency problem can be resolved in three ways. One is via an automatic, self-disciplining system, such as the textbook gold standard or freely floating exchange rates without official intervention. A second approach relies on collective adherence to the decisions of some international-or, more properly, supranational-institution, which would substitute some mixture of rules and discretionary judgment for automaticity in developing consistent compromises among member countries. A third approach, variously known as the "key currency" or " $n$th country" solution, calls for one country (or group of countries) to eschew its own targets (thus ensuring the consistency of the other $n-1$ targets) in favor of taking special responsibility for the operation of the system itself.

In the real world, of course, things are never as clear-cut as this taxonomy suggests, and some mixture of these three ordering principles has generally prevailed. Even during the heyday of the classical gold standard from 1879 to 1914, the international system apparently operated a good deal less automatically than textbooks suggest. And it functioned successfully, in the opinion of many, only because Great Britain assumed special responsibilities as the center country. After the First World War the United States began to take international monetary leadership, although the monetary chaos that characterized most of the interwar period attested, in one view, to the reluctance and inexperience with which this country exercised that role. ${ }^{1}$ Certainly the concept of "dominant countries" and "key currencies" underlay the Tripartite Monetary Agreement of 1936, in which the governments of the United States, Great Britain, and France agreed to cooperate

1. See Charles P. Kindleberger, The World in Depression, 1929-1939 (University of California Press, 1973). 
in the defense of exchange rates against international flows of hot money. Despite its failure to restore order to the international monetary system, the Tripartite Agreement did set an important precedent for international monetary cooperation.

\section{THE DOLLAR IN THE BRETTON WOODS SYSTEM}

The Articles of Agreement of the International Monetary Fund reflect two basic principles: that of collective or cooperative responsibility for the operation of the international monetary system and, after a transition period, that of legal symmetry or equality in the rights and obligations of the member countries. But the rules of the system were far from automatic or self-enforcing; in the amount of discretionary decisionmaking power ostensibly ceded to the IMF, the system envisaged at Bretton Woods came closer than any previous arrangement to invoking the principle of adherence to the judgments of an international institution.

Among those whose views were rejected at Bretton Woods were the proponents of a "key currency" system, who took the Tripartite Agreement of 1936 as their model. ${ }^{2}$ And yet, from the very beginning, the Bretton Woods system drifted away from its original concept of equality toward reliance on a single key currency, the U.S. dollar. During the first decade or so after Bretton Woods, it was the United States, rather than the IMF, that made the bulk of loans to member countries experiencing balance-ofpayments difficulties. And it was the United States, rather than the Fund, that took the lead in urging other countries to adopt policies to stabilize their payments positions, including the substantial devaluations of the currencies of most major industrialized countries against the dollar in 1949.

The asymmetrical role of the dollar in the Bretton Woods system developed in several different dimensions. Because it was backed by the world's largest and strongest economy and because it was, until 1958, the only major currency that enjoyed market convertibility, the dollar served as the major international vehicle, or transaction, currency, even in transactions involving no American resident. Second, under the Articles of Agreement all countries were to maintain the value of their currencies within a stated range of parity, but the United States undertook to discharge this obligation

2. See Harry G. Johnson, "Political Economy Aspects of International Monetary Reform," Journal of International Economics, Vol. 2 (September 1972), pp. 410-11. 
by buying and selling gold for monetary purposes at the fixed price of $\$ 35$ per fine ounce, while other countries did so through intervention in the foreign exchange markets. This unique obligation reflected, in turn, another aspect of asymmetry: as other currencies became convertible, most monetary authorities used the dollar in exchange market intervention. The dollar also became the numeraire of the IMF in which most currencies were defined, while it itself was defined in terms of gold.

The Articles of Agreement provided no convenient mechanism for the secular growth of international reserves. As the combination of newly mined gold for monetary purposes and positions in the International Monetary Fund failed to expand sufficiently to keep up with world liquidity needs, the dollar filled the breach, and, in fact, became the major source of growth in international reserves in the postwar period. Finally, because of its special place in the system, the United States played the passive, or $n$ thcountry, role in the exchange-rate adjustment process; other countries from time to time changed the par value of their currencies against the dollar and gold, but the value of the dollar itself remained fixed in relation to gold and therefore to other currencies collectively.

The progression from the "dollar shortage" of the 1950s to the "dollar glut" of the late 1960s and the cumulating problems and ultimate collapse of the gold-dollar standard are too well known to require repeating, although controversy over their basic causes continues. In the view of Triffin, who predicted the collapse of the gold-dollar standard as early as $1960,{ }^{3}$ deterioration of any dominant-currency standard is inevitable. He traces this deterioration through an initial stage of financial irresponsibility resulting from the "exorbitant privilege" of a dominant currency; a second stage of currency overvaluation, a loss of jobs and markets from the resulting demand shift, and an accompanying fall in interest rates which aggravates the balance-of-payments problem; and a third and final stage of revived protectionism, interest rate reductions, skyrocketing payments deficit, and an ultimately irresistible wave of speculation against the dominant currency. ${ }^{4}$ Whether or not one accepts this scenario in toto, a decline in the liquidity ratio (the ratio of reserve assets to liquid liabilities) is plainly an inevitable accompaniment of the reserve currency function. By mid-1971, this dete-

3. Robert Triffin, Gold and the Dollar Crisis: The Future of Convertibility (Yale University Press, 1960).

4. See Robert Triffin, "International Monetary Collapse and Reconstruction in April 1972,” Journal of International Economics, Vol. 2 (September 1972), pp. 376-78. 
riorating liquidity position had combined with the accelerating U.S. inflation to produce a crisis of confidence and a flight from the dollar.

\section{Aspects of Symmetry in Recent Reform Proposals}

The Smithsonian Agreement of December 1971 was a first step toward building a new international monetary order out of the rubble of the Bretton Woods system. In retrospect, the effort to replace one pattern of fixed exchange rates with another looks like a case of putting Humpty Dumpty together again. But it established two important points. First, the "U.S. balance-of-payments problem" was at least in part a problem of the international monetary system itself. Such a diagnosis implied that the cure-an appropriate pattern of exchange rates-was a matter for multilateral rather than unilateral or bilateral concern. Second, the United States was abandoning its passive, or $n$ th-country, role in the adjustment process and now had explicit balance-of-payments targets of its own. ${ }^{5}$

\section{THE U.S. PROPOSAL}

The concept of symmetry implied by the Smithsonian negotiations was made explicit in the U.S. proposal for international monetary reform put forward nine months later. ${ }^{6}$ This symmetry had several aspects. One was the need for a symmetrical stance toward surplus and deficit countries in the adjustment process (in contrast with the Bretton Woods system, which exerted greater pressure for adjustment on deficit than on surplus countries, apparently producing some devaluation, or at least antirevaluation, bias). A second was symmetrical treatment of the dollar and other currencies, a

5. The United States had instituted a variety of measures during the 1960s aimed at improving one portion or another of its balance-of-payments accounts. But these measures were initiated at least partly in response to the urgings of foreign governments.

6. See George P. Shultz, "Statement by the Governor of the Fund and Bank for the United States," in International Monetary Fund, Summary Proceedings of the Twentyseventh Annual Meeting of the Board of Governors, September 1972 (1972), pp. 34-44; Economic Report of the President, January 1973, App. A, Supplement to Chap. 5; "Quantitative Indicators from the Point of View of the Overall Operation of the System" (memorandum submitted by the U.S. Deputies of the Committee of Twenty to the Secretary, International Monetary Fund, May 17, 1973; processed). 
departure from the passive role in exchange rate adjustment that the United States had previously played. ${ }^{7}$

This second point had two implications. First, it meant that the United States should be able to initiate a change in the parity of the dollar, not simply vis-à-vis gold but effectively vis-à-vis other currencies as well. Under the Articles of Agreement(Section 5), the United States, like other countries, had the right to change the dollar parity in conformity with the standard IMF criterion of "fundamental disequilibrium." But, until the Smithsonian Agreement, it was widely believed that an alteration in the gold parity of the dollar would set in train parallel alterations in other currencies, thus preventing any shift in the effective exchange rate of the dollar. Second, U.S. "freedom of adjustment action" implied widening the permissible band of variation in the market rates of exchange between the dollar and other currencies. Previously, because the dollar was almost universally used as the intervention currency, the permissible band of variation around parity was twice as wide for any two nondollar currencies as it was for the dollar and another currency. That is, permissible bands of variation of 1 percent around dollar-mark parity and dollar-franc parity necessarily implied a band of 2 percent around the cross-rate parity between the mark and the franc, within which no dollar intervention was required of either Germany or France. Giving the dollar the same freedom of action as other currencies within the bands around parity meant establishing some system of multicurrency or other nondollar intervention.

Besides emphasizing the need for greater symmetry in the adjustment process, the U.S. proposals also implied a reduction in the special role of the dollar in international reserves, even though, at the time, the world was operating on a "pure dollar standard" for the first time. The United States proposed that the special drawing rights (SDRs) issued by the International Monetary Fund become the formal numeraire of the system and the major source of new reserves, and that the place of gold and national currencies, primarily the U.S. dollar, in reserves be gradually reduced. This arrangement would permit the international community to determine collectively

7. A proposal advocating symmetrical adjustment pressures on surplus and deficit countries had been put forward, unsuccessfully, by Lord Keynes at Bretton Woods. For a discussion of asymmetry in the international monetary system, see Peter B. Kenen, "Convertibility and Consolidation: A Survey of Options for Reform," in American Economic Association, Papers and Proceedings of the Eighty-fifth Annual Meeting, 1972 (American Economic Review, Vol. 63, May 1973), pp. 191-94. 
the stock and growth rate of international reserves, correcting an inadequacy of the Bretton Woods system. Finally, the U.S. proposal made clear that should the United States resume convertibility of dollar balances held by foreign official institutions, it would do so not through a renewal of the unique responsibility to buy and sell gold at a fixed price, but only through the exercise of obligations parallel to those assumed by other countries.

By ending the passive, or $n$ th-country, role of the United States in payments adjustment and the creation of reserves, the U.S. proposal would eliminate the major mechanism by which consistency of national targets and policies had been achieved under the Bretton Woods system. The proposal specifically recognized and addressed the problem of consistency, seeking to ensure it by a delicate combination of automatic rules and adherence to the discretionary judgment of the IMF.

The U.S. proposal for the international monetary system recognized the need for compatibility among the adjustment process, the mechanism for creating reserves, and the provisions for convertibility of foreign exchange balances into primary reserve assets. A tight adjustment system, requiring rapid elimination of payments disequilibria, implies relatively small reserves; in the limit, with freely flexible exchange rates, continuous clearing of exchange markets, and thus the prevention of payments disequilibria, needed levels of official reserves would approach zero. A loose adjustment system, on the other hand, in which payments disequilibria were allowed to become very large or persist for a long time, would require larger reserves to finance the payments imbalances. Similarly, if it is to be both feasible and credible, a fixed-rate system that offers convertibility of foreign exchange balances into primary reserve assets must provide for a combination of primary reserve growth (to meet convertibility commitments) and adjustment discipline (to limit the accumulation of balances for which conversion might be demanded).

The United States proposed to assure consistency, symmetry, and effectiveness in the adjustment process by the so-called reserve indicator mechanism. Specifically, disproportionate gains or losses in reserves should serve as "objective indicators," or presumptive criteria, of the need for adjustment and, in some cases, for the application of international pressures on countries to bring about such adjustment.

Finally, the U.S. proposal stressed the need for consistency between the rules governing the international monetary system on the one hand and those affecting trade and investment relationships on the other. The United 
States made no specific proposal on this issue, and little further work has been done on harmonizing the rules of the IMF and the GATT (General Agreement on Tariffs and Trade). Nonetheless, for reasons pointed out earlier, convertibility obligations can be viable in the long run only if combined with an effective adjustment mechanism. And no system of monetary adjustment can operate effectively if it is thwarted by commercial or investment policies that distort or rigidify trade and investment relationships.

In proposing substantial reductions in the dominant role of the U.S. dollar and the United States, and yet stopping well short of an automatic, self-disciplining system, the American reform proposal clearly implied the need for stronger international institutions. In the words of the Shultz statement, "International decision making will not be credible or effective unless it is carried out by representatives who clearly carry a high stature and influence in the councils of their own governments. Our international institutions will need to reflect that reality...." a ministerial-level body representing the constituent nations or nationgroups of the IMF, was formed to develop a blueprint for a reformed international monetary system as a first step in this institutional upgrading process.

\section{THE COMMITTEE OF TWENTY'S OUTLINE OF REFORM}

The Outline of Reform produced by the Committee of Twenty is in effect two documents. ${ }^{9}$ Part I is devoted to a description of "The Reformed System" which in many of its essential features is very close to the U.S. proposal. It reflects the same relatively conservative view of the international monetary system, "with the exchange rate regime based on stable but adjustable par values and with floating rates recognized as providing a useful technique in particular situations." It indicates a similar concern for a more symmetrical system, citing among "the main features of the international monetary reform" "an effective and symmetrical adjustment process ..."; "the introduction of an appropriate form of convertibility

8. IMF, Summary Proceedings, p. 42.

9. International Monetary Fund, "Outline of Reform," in International Monetary Reform: Documents of the Committee of Twenty (IMF, 1974), pp. 7-48. The discussion here is not a comprehensive survey of the reform proposal, but focuses only on those aspects relating to the issue under consideration. In particular, I omit any discussion of one very important aspect of international monetary reform: the relation of the international monetary system to the needs of developing countries. 
for the settlement of imbalances, with symmetrical obligations on all countries" (including those whose currencies are held in official reserves); and "better international management of global liquidity, with the SDR becoming the principal reserve asset and the role of gold and of reserve currencies being reduced." 10

The Committee of Twenty outline also echoes the U.S. proposal in its concern for consistency within and among the various aspects of the reformed system, citing also among the main features "consistency between arrangements for adjustment, convertibility, and global liquidity" and pointing out that "it is agreed that the principles which govern the international monetary system and arrangements in these related areas [of international trade, capital, investment, and development assistance] must be consistent." As regards capital movements, the outline notes more specifically the need for cooperation "in actions designed to limit disequilibrating capital flows and in arrangements to finance and offset them." Finally, provision is made for the necessary upgrading and strengthening of the International Monetary Fund in the form of a permanent council, with one member (at the ministerial level) from each Fund constituency, "to supervise the management and adaptation of the monetary system, to oversee the continuing operation of the adjustment process, and to deal with sudden disturbances which might threaten the system."11

Whereas the proposals for reform of the international monetary system put forth by the United States in September 1972 and by the Committee of Twenty in June 1974 were similar, the contexts in which they were profferred were vastly different. The U.S. proposal was offered at a time of widespread commitment to the pattern of exchange rates established under the Smithsonian Agreement. The final report of the Committee of Twenty, on the other hand, came at a time when the Smithsonian Agreement had been consigned to history, when the world had had more than a year's experience with widespread floating of exchange rates, and when an early restoration of any par-value system was no longer a serious option.

Part II of the Outline of Reform, entitled "Immediate Steps," focuses on criteria for a workable floating-rate system for the present, rather than on a fixed-rate system to be implemented in the far-off future, if at all. The two parts of the document are consistent in spirit, however. Both imply a larger and more influential role for the IMF, particularly in the surveillance

10. Ibid., p. 8.

11. Ibid., pp. 8, 13, 18 . 
of the international adjustment mechanism, including such aspects of national policy as management of the balance of payments, exchange rates, and reserves. Both depart sharply from a system based on a key currency toward one that embodies equality of obligations and criteria for conduct among all currencies as regards adjustments, asset settlement, and reserves. And both reflect a pervasive concern for consistency among all aspects of the system to minimize the likelihood of offsetting and potentially destructive behavior.

This second part of the proposal provides, in general terms, for close international consultation on and IMF surveillance of balance-of-payments adjustment. The Fund is instructed "to gain further experience in the use of objective indicators, including reserve indicators, on an experimental basis" and to determine "what is a disproportionate movement in reserves... in the light of the broad objectives of member countries for the development of their reserves over a period ahead ...."12 Of much greater immediate importance are the guidelines for floating, designed as a code for central bank intervention in exchange markets. The aim is to avoid competitive devaluation or undervaluation and to promote international consistency in what is clearly expected to be a system of managed rather than freely flexible exchange rates. The proposed guidelines provide that a country should intervene in the foreign exchange market "to prevent or moderate sharp and disruptive" day-to-day or week-to-week fluctuations in the exchange value of its currency-that is, to help maintain orderly market conditions. They provide also that a country may intervene to moderate month-to-month or quarter-to-quarter movements in its exchange rate, particularly if "factors recognized to be temporary are at work," although generally speaking a country should avoid intervening to accentuate movements in the value of its currency. ${ }^{13}$

As to longer-range intervention, the guidelines for floating lean heavily on the concept of a target zone or range for the exchange rate and for reserves, to be determined jointly by the country concerned and the Fund. Intervention to move in the direction of the reserve target, or to moderate movements away from it, would be encouraged, while intervention having the opposite effects would be frowned on. In the prominence given to reserve indicators as a criterion for judging actions to affect balance-ofpayments adjustment, the guidelines for floating look much like the original

12. Ibid., p. 19.

13. The guidelines, including the quotations, are from ibid., Annex 4. 
U.S. proposal, adapted to a world of managed floats rather than of "fixed but adjustable" parities.

The outline of an interim system also calls for Fund surveillance and management of the supply of global liquidity. Such management would involve the allocation (issuance) and cancellation of SDRs so as to ensure consistency between the determination of global reserve needs and other provisions of the reform, in particular those for convertibility and adjustment. Fund review of the aggregate volume of foreign exchange reserves is called for, as are steps to secure "orderly reductions" should reserves increase excessively. However, the proposal leaves unsettled the important question of whether asset settlement should be mandatory, meaning that all holdings of currencies in official reserves above a predetermined amount must be converted into primary reserve assets, or "on demand," meaning that conversion would take place only if either the holding country or the issuing country requested it. ${ }^{14}$ Obviously, a mandatory scheme would entail much closer international control over the aggregate volume of international reserves.

The outline also notes the importance of coordination and consistency between the monetary and trading systems, and, especially, of avoiding restrictions on trade and payments for balance-of-payments purposes. To that end, there is appended to the Outline of Reform a declaration whose signatories would pledge themselves not to introduce or intensify trade or other current-account restrictions for balance-of-payments purposes "without a prior finding by the Fund [of] justification." 15

The pressures for symmetry implicit in the guidelines for floating and in the concept of a mandatory asset settlement system that would reduce or prevent the accumulation of currencies in official reserves are clear enough. In addition, the Committee of Twenty proposal, by providing for multicurrency or SDR intervention, would at least attenuate the role of the dollar as an intervention currency, with its attendant restrictions on variations in the exchange value of the dollar. The delineation of such an alternative scheme is complicated by the fact that, without a passive, $n$th country, precise rules of behavior are essential to prevent mutually contradictory intervention by two or more countries.

Finally, the outline proposes a new way of valuing SDRs, in some predetermined combination or "basket" of leading currencies, rather than in

14. For a discussion of the alternatives, see ibid., Annex 5.

15. Ibid., p. 23. 
terms of dollars or gold. Of several variants, the one selected for a two-year trial is the so-called "standard basket" technique. Under this scheme, the appreciation (depreciation) of any currency in the basket in terms of all other currencies would raise (lower) the value of the SDR in terms of all other currencies. ${ }^{16}$ The purpose of a "basket" SDR would be to provide a numeraire that had stability in terms of the average value of the major currencies in a world where all currencies, including the dollar, moved freely against one another. Implicit in this concept is the expectation that, over the long run, such a unit of account would also have greater stability of worldwide purchasing power than any individual currency. Corresponding to such use of a basket SDR is the measurement of effective changes in exchange rates, computed as an average of changes in individual bilateral rates, weighted according to trade shares. Such measures have been used increasingly since the advent of generalized floating. ${ }^{17}$

\section{The United States, the Dollar, and the International Monetary System}

A few years ago, a number of American academics noted a certain ambivalence in the attitude of the European countries toward the United States and the international monetary system. On the one hand, the Europeans exerted increasing pressure on the United States to reduce its payments deficit and "put its house in order." At the same time, they were clearly loath to appreciate currencies that were undervalued or to undertake other liberalizing actions to reduce their own collective payments surplus which was, in large measure, the counterpart of the U.S. deficit.

Today, it is the United States that is displaying ambivalence and a certain inconsistency toward its role in the international monetary system. On the one hand, the United States has fought hard - and apparently successfullyfor greater symmetry in the new system, for an end to its unique converti-

16. Although such a fixed-weight basket, incorporating the currencies of the countries most important in international trade, is reasonable as an interim measure, presumably any permanent scheme would have to allow for changing both the weights and the composition of the basket as the relative trading importance of countries changed. The weighting scheme is detailed in International Monetary Fund, IMF Survey, Vol. 3 (June 17, 1974), p. 185.

17. The calculations of several indexes of effective changes in exchange rates are outlined in Economic Report of the President, February 1974, Supplement to Chap. 6, pp. 220-26. 
bility obligations, for greater freedom to exercise active control over its own exchange rate. At the same time, it seems reluctant to abolish the special role of the dollar as a reserve currency. For example, the United States has opposed a system of mandatory convertibility of foreign exchange balances in favor of a looser system of convertibility on demand, arguing that countries that prefer to hold foreign exchange (primarily dollars) in their reserves should be free to do so unless the issuer of the reserve currency objects. Similarly, discussing a system of managed floating, U.S. representatives have favored "ceiling intervention" (under which countries whose currencies are appreciating would purchase weaker currencies to slow or halt the appreciation) over "floor intervention" (countries whose currencies are depreciating would sell stronger currencies for their own). Floor intervention would hold down the creation of foreign exchange reserves and thus enhance collective control over creation of international reserves. Ceiling intervention, on the other hand, would be associated with acquisition of dollars by countries with strong currencies and thus tend to perpetuate the reserve-currency role of the dollar. And yet, as Cooper has pointed out, even the reserve roles occupied by the dollar in the past have left a legacy of difficulties for any system based on full symmetry of rights and obligations. The continuation of this reserve role into the future would greatlyperhaps hopelessly-complicate the operation of a more symmetrical international monetary system. ${ }^{18}$

This ambivalence on the part of the United States, it can be argued, reflects uneven changes in its role in the world economy. In "real" terms, the pattern has been one of steady, gradual decline from the overwhelming dominance the United States exerted immediately after World War II. Concomitantly, the sensitivity of the U.S. economy to influences beyond its own borders has increased significantly, although the United States is still far less open than other countries in the noncommunist world. In the financial sphere, on the other hand, the international positions of the United States and of the dollar (which are not always identical) have, if anything, strengthened throughout most of the postwar era. Any decline in their dominance has occurred only since about 1970, with the final crisis of confidence of the Bretton Woods system and the highly fluid situation since then. At present it is impossible to tell whether this rather small reduction

18. Richard N. Cooper, "Eurodollars, Reserve Dollars, and Asymmetries in the International Monetary System," Journal of International Economics, Vol. 2 (September 1972), pp. 325-44. 
Table 1. The U.S. Share in the World Economy, Selected Economic and Financial Measures, 1950, 1960, 1970, and 1973

Percent of world total

\begin{tabular}{lcccc}
\hline \multicolumn{1}{c}{ Measure } & 1950 & 1960 & 1970 & 1973 \\
\hline Gross national product & 39 & 34 & 30 & 28 \\
Production of motor vehicles & 76 & 48 & 31 & n.a. \\
Production of steel & 46 & 28 & 20 & n.a. \\
International reserves $^{\mathrm{a}}$ & 50 & 32 & 16 & 8 \\
Exports $_{\text {Consumption of materials }}{ }^{\mathrm{b}}$ & 16 & 15 & 14 & $12^{\mathrm{o}}$ \\
& 42 & n.a. & 27 & n.a. \\
\hline
\end{tabular}

Sources: 1973-International Economic Report of the President, February 1974, pp. 2, 4, and International Monetary Fund, International Financial Statistics, Vol. 27 (May 1974), pp. 18-19; materials consumptionMaterials Needs and the Environment Today and Tomorrow, Final Report of the National Commission on Materials Policy (1973), Table 9.1, p. 9-4; other data are from Peter G. Peterson, The United States in the Changing World Economy, Vol. 2, Background Material (U.S. Government Printing Office, 1971), Charts 1,9, $11,12$.

a. End of period. Includes gold, special drawing rights, reserve position in the International Monetary Fund, and foreign exchange.

b. Materials are here defined as natural resources intended to be used by industry for the production of goods, except food.

c. 1972 data.

n.a. Not available.

in the international financial role of the dollar is temporary and will be halted or reversed once the international monetary system settles down to more predictable behavior, or whether it marks the first stage of a significant shift in the preferences of participants in international markets.

\section{The United States in the World Economy}

The change in the real position of the United States in the world economy since 1950 is summarized briefly in Table 1. While the United States remained the world's largest economy in 1973, with a gross national product accounting for nearly half that of all countries of the Organisation for Economic Co-operation and Development and running more than three times that of Japan, the second largest noncommunist country, ${ }^{19}$ its share of world GNP had fallen by more than one-fourth since 1950. The U.S. shares of world exports and international reserves have also declined steadily, the latter much more dramatically than the former. Capital exports have behaved differently. In 1971, as in 1961, the United States held almost 70 percent of the total direct investment claims of the world's major capital-

19. International Economic Report of the President, February 1974, p. 2. 
exporting nations, despite the introduction from 1963 onward of programs to retard outflows of U.S. capital. ${ }^{20}$

Meanwhile, the United States has become a more open economy and more sensitive to influences from abroad. The ratio of imports to U.S. GNP has grown from 4.4 percent in 1950 to 7.4 percent in 1973, paralleling the share of exports (up from 4.6 percent to 7.8 percent), despite substantial swings in the U.S. trade balance during the period. ${ }^{21}$ The openness of other industrialized nations also increased substantially during 1950-73. The point is that the United States is much more deeply involved in interdependence as a two-way proposition than ever before.

The averages just described obscure the much heavier dependence of the U.S. economy on other countries for critical materials-especially on the third world for natural resources. The resulting influence of the producing countries on the U.S. economy may well deepen if they can imitate the OPEC countries (those in the Organisation of Petroleum Exporting Countries) in exploiting their potential oligopoly power.

The continuing, albeit reduced, importance of the United States in the world economy combines with the greater sensitivity of the domestic economy to external influences to create a channel through which U.S. policies and experiences have an extra, indirect impact on the U.S. economy via their effects on the rest of the world. For example, perhaps one-quarter of the 39 percent increase in the dollar prices of thirteen major industrial raw materials and slightly less than one-fifth of the 65 percent increase in the prices of nine foodstuffs during the first three quarters of 1973 were attributable to the depreciation of the dollar over the same period. ${ }^{22}$ Clearly, these increases contributed substantially to the general increase in U.S. prices. Indeed, recent experience makes clear that predictions of the impact that effective depreciation of the dollar would have on U.S. inflation were far too low. These estimates were generally based on the conventional Keynesian model, with elasticities of substitution between foreign and

20. International Monetary Fund, Balance of Payments Yearbook, Vol. 17 (1960-64) and Vol. 25 (1968-72).

21. Survey of Current Business, Vol. 38 (December 1958), p. 13, and Vol. 54 (October 1974), p. S-1.

22. Edward M. Bernstein, "The Inflation Problem in the United States," Quarterly Review and Investment Survey, Fourth Quarter 1973 (New York: Model, Roland \& Co., 1973), pp. 2-4. These items are the components of the index of spot market prices compiled by the Bureau of Labor Statistics. 
domestic goods assumed to be relatively low. Under these assumptions, depreciation of the dollar would affect the domestic price level only through the higher prices of imported finished goods or inputs. Since imports constitute only some 7.4 percent of U.S. GNP, an effective dollar depreciation of 10 percent could raise the price level, as measured by the GNP deflator, by no more than $3 / 4$ of 1 percent. Further, the relative importance of the United States in world markets makes it unlikely that the depreciation would be passed through fully into the dollar prices of imports.

In reality, of course, elasticities of substitution between foreign and domestic goods may be quite high in certain sectors, and realistic estimates of the impact of depreciation on domestic prices must be based on models that incorporate its effects on the entire tradable-goods sector. Although systematic evidence is still scarce, two studies have yielded reasonably consistent results. One, utilizing regression analysis for the period 1959-71, estimated that the U.S. consumer price index would rise by about 20 percent of the effective dollar depreciation. ${ }^{23}$ The second estimated that the 10 percent effective depreciation of the dollar between November 1972 and August 1973 accounted for between 1.9 and 2.3 percentage points of the U.S. wholesale inflation over that period. ${ }^{24}$

These studies may still not capture the total indirect effects on prices in industries producing exportable and import-competing goods and, through effects on wages, even in sectors producing nontradable output. In particular, the improvement in the net balance on goods and services from a deficit of $\$ 0.8$ billion in 1972:4 to a surplus of $\$ 11.6$ billion in 1973:4 (both in 1958 dollars) represented 38 percent of the total increase in real GNP over the period. When key industries were straining against capacity, this substantial diversion from domestic to foreign absorption must have had pervasive effects on the domestic price level. Clearly, the feedback from the exchange rate of the dollar to the U.S. price level, which took many by surprise in 1973, is too large to be ignored.

A similar, if less dramatic, feedback can be observed in domestic corporate profits. The share of foreign earnings in the profits of U.S. corporations

23. Sung Y. Kwack, "The Effects of Foreign Inflation on Domestic Prices and the Relative Price Advantage of Exchange Rate Changes" (paper presented at the Conference on Effects of Exchange Rate Adjustments, U.S. Department of the Treasury, April 5, 1974; processed).

24. William Nordhaus and John Shoven, "Inflation 1973: The Year of Infamy," Challenge, Vol. 17 (May/June 1974), pp. 14-22. 
Table 2. Share of Foreign Earnings in Profits of U.S. Corporations, Selected Years, 1950-72

Millions of dollars, except as noted

\begin{tabular}{|c|c|c|c|c|c|c|c|}
\hline $\begin{array}{c}\text { Profit } \\
\text { calculation }\end{array}$ & 1950 & 1955 & 1960 & 1965 & 1970 & 1971 & 1972 \\
\hline $\begin{array}{l}\text { Total U.S. corporate } \\
\text { profits before taxes }\end{array}$ & 42,600 & 48,600 & 49,700 & 77,800 & 74,000 & 85,100 & 98,000 \\
\hline $\begin{array}{l}\text { U.S. direct investments } \\
\text { abroad } \\
\text { Earnings }{ }^{\mathrm{a}}\end{array}$ & 1,769 & 2,811 & 3,566 & 5,460 & 8,789 & 10,299 & $12,386 \mathrm{p}$ \\
\hline $\begin{array}{l}\text { Interest, dividends, and } \\
\text { branch earnings of } \\
\text { U.S. investors }\end{array}$ & 1,294 & 1,912 & 2,355 & 3,963 & 6,001 & 7,295 & $8,004 p$ \\
\hline $\begin{array}{l}\text { Percent of total U.S. } \\
\quad \text { corporate profits } \\
\text { Foreign earnings }\end{array}$ & 4.2 & 5.8 & 7.2 & 7.0 & 11.9 & 12.1 & 12.6 \\
\hline $\begin{array}{l}\text { Interest, dividends, and } \\
\text { branch earnings of } \\
\text { U.S. investors }\end{array}$ & 3.0 & 3.9 & 4.7 & 5.1 & 8.1 & 8.6 & 8.2 \\
\hline
\end{tabular}

Sources: Profits-U.S. Bureau of the Census, Statistical Abstract of the United States, 1974 (1974), Table 802, p. 488; other data-Survey of Current Business, various issues.

a. U.S. parents' share in the earnings of their foreign subsidiaries and branches, after payment of foreign income tax, preferred dividends, and interest.

b. The sum of dividends, preferred dividends, and interest received by or credited to the account of U.S. direct investors-all net of foreign withholding taxes-plus branch earnings after foreign taxes; all before U.S. taxes.

p Preliminary.

has roughly tripled from 1950 to 1972 (see Table 2). At the same time, the share of sales of local affiliates of U.S. firms in the GNP of such important partner countries as Canada, the United Kingdom, Germany, and France has been increasing steadily. ${ }^{25}$ The circular flow from developments here through U.S. affiliates to other economies and then back again through the earnings of those affiliates to U.S. corporate profits plainly has growing significance for real economic activity in the United States.

\section{The International Financial Roles of the Dollar}

While on the real side the relative importance of the United States in the world economy has been declining gradually over the postwar period, the role of the U.S. dollar in international financial transactions has expanded, at times dramatically. Even the major upheavals in international financial

25. See Implications of Multinational Firms for World Trade and Investment and for U.S. Trade and Labor, Report to the Senate Committee on Finance, 93 Cong. 1 sess. (1973); and Organisation for Economic Co-operation and Development, National Accounts of OECD Countries, 1960-1971 (Paris: OECD, no date). 
markets in the past few years have not yet significantly affected the financial importance of the dollar, and may not in the future.

A quick overview of the international financial role of the dollar can be gleaned from Table 3 , which depicts the international liquidity position of the United States since 1957. Between 1957 and 1970 the deterioration in the U.S. net liquidity position was gradual enough to be attributable primarily to the expanding international banking or intermediation function that the United States performed as the major supplier of private and official international reserves. From 1970 on, when the U.S. liquidity position vis-à-vis commercial banks actually improved and the accelerated overall deterioration was due entirely to the explosion in liquid liabilities to foreign official institutions, the change is more reasonably interpreted as a weakening of the international position of the dollar.

Table 3 indicates that as of the end of 1973, the total liquid claims on U.S. residents held by foreigners, both private and official, amounted to slightly more than $\$ 90$ billion. But this figure tells only part of the story. As of the same date, the net size of the Eurocurrency market was estimated to be $\$ 155$ billion, of which some 72 percent, or $\$ 112$ billion, was in Eurodollars. Thus, a total of some $\$ 200$ billion of liquid dollar-denominated assets was held by foreigners at the end of 1973 , as compared with $\$ 100$ billion in 1970 and $\$ 40$ billion in 1965 .

Actually, the numbers, while useful in suggesting the general magnitude of the phenomenon, obscure the multiple roles the dollar plays. As many as six separate functions of an international "key" or "vehicle" currency have been identified: the transactions, quotation, and asset-currency roles in private transactions, and-in rough correspondence-the intervention, unit-of-account, and reserve-currency roles in official transactions. ${ }^{26} \mathrm{Al}$ though these roles are logically distinct, efficiency is likely to be enhanced by combining them. The dollar does, in fact, function in all six aspects; and I consider each in evaluating the past, present, and future of the dollar in the international monetary system.

\section{THE DOLLAR'S ROLE IN PRIVATE TRANSACTIONS}

In delineating the international roles played by the dollar, distinguishing the transactions from the asset functions is difficult, since there is no effec-

26. Benjamin J. Cohen, The Future of Sterling as an International Currency (St. Martin's Press, 1971), Chap. 1. 
tive means of estimating the portions of liquid balances held for each purpose. For gauging the dollar's role in international trade transactions, the general identity of the quotation or invoice currency with the currency of settlement proves useful.

For the period 1968-71, somewhere between one-quarter and one-third of world trade is thought to have been invoiced and transacted in dollars. ${ }^{27}$ Although the U.S. share of world trade is substantial (15 percent in 1970), the much larger estimated share of the dollar in trade transactions indicates that it also plays a significant "third currency" role in transactions in which no U.S. resident is involved. One rough estimate indicates that about 75 percent of transactions in third-country currencies are denominated in dollars, with the pound sterling serving as the only other major third-country currency. ${ }^{28}$ Unfortunately, no systematic evidence is available to indicate whether this role of the dollar has altered significantly in recent years. There are anecdotal reports of shifts away from dollar invoicing since 1971, but few hard numbers. A study based on U.S. customs data found that, while the proportion of U.S. imports from Germany invoiced in dollars had decreased and the proportion invoiced in Deutsche marks increased between 1971 and 1973, the proportion of U.S. imports from Japan invoiced in dollars had increased. ${ }^{29}$

In discussing the growth of liquid dollar assets held by nonofficial foreigners, one must distinguish American dollar holdings that are direct liabilities of U.S. residents from Eurodollar holdings that, although denominated in dollars, are held outside the United States and are liabilities of foreign rather than domestic residents. Most of the growth in recent years of dollar-denominated assets held by nonofficial foreigners has been in the latter form.

The liquid American dollar holdings of foreign private nonbanks ("other foreigners" in Table 3), for example, increased by only 130 percent over the period 1957-73, while U.S. trade increased by some 300 percent in nominal value, world trade by 400 percent, and international financial transactions arising from dollar-denominated capital movements by even

27. Cohen, Future of Sterling, p. 18; and Sven Grassman, "A Fundamental Symmetry in International Payment Patterns," Journal of International Economics, Vol. 3 (May 1973), pp. 115-16.

28. Ibid., p. 110. Grassman's estimates are extrapolated from Swedish data for 1968, reinforced by observations for Denmark and West Germany.

29. Stephen P. Magee, "U.S. Import Prices in the Currency-Contract Period," Brookings Papers on Economic Activity (1:1974), Table 2, pp. 126-27. 


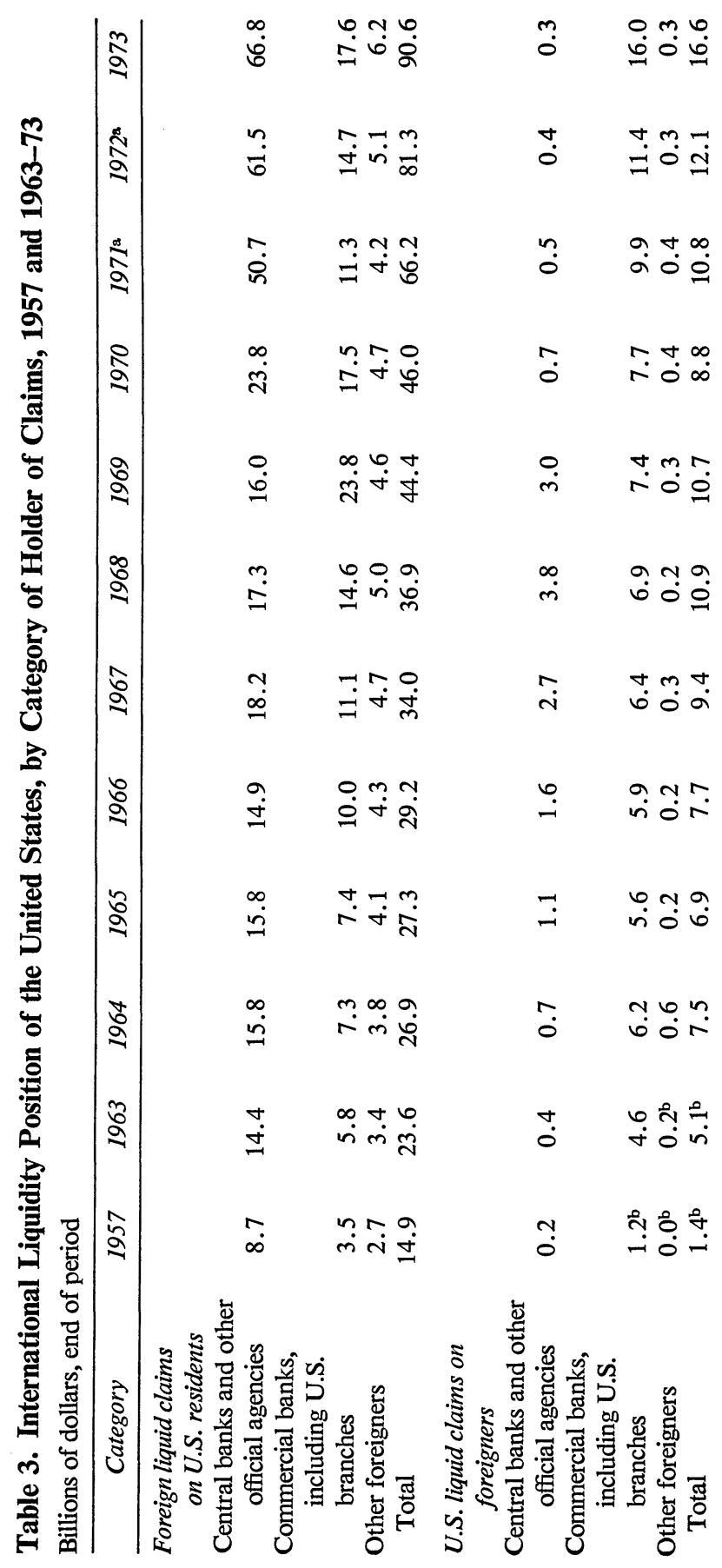




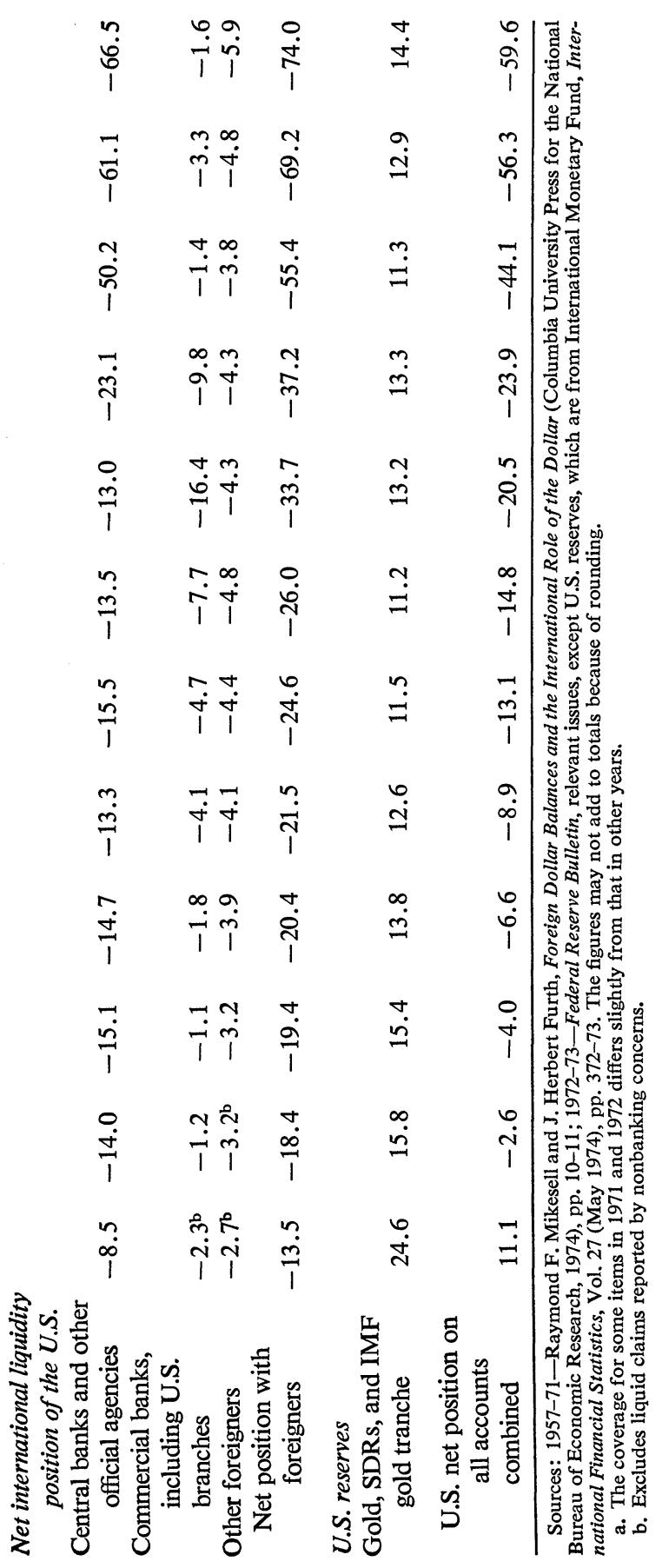


greater proportions. Since such claims, consisting primarily of demand and short-term time deposits in U.S. banks, are generally held for transactions rather than investment purposes, their slow rise suggests that the growth of multinational banks and nonfinancial corporations, as well as the expansion of Eurodollar deposits, may well have reduced the demand for short-term deposits in the United States. ${ }^{30}$ In any case, the diminishing importance of such holdings relative to international transactions was an established trend long before the decline and fall of the Bretton Woods system; and, in fact, such balances actually spurted upward in 1972 and 1973, a time of maximum fluctuation and uncertainty for the dollar in foreign exchange markets.

The liquid holdings of American dollar balances by foreign commercial banks grew fairly steadily until 1969 , and since that time, as indicated in Table 3, have fluctuated substantially without any discernible trend. A large proportion of these assets represents the internal accounting entries of multinational banks, particularly U.S. commercial bank borrowings from and repayments to the Eurodollar market through their foreign branches. For this reason, "it is impossible to determine either the amounts of foreign liquid dollar balances which serve an international transactions function or the amounts which represent the American dollar asset components of the liquid interest-earning portfolios of foreign commercial banks." 31

In contrast to the relatively modest growth of foreign private holdings of American dollar balances over the past decade, Eurodollar holdingsdollar-denominated deposits held in banks outside the United States, primarily in London-have grown explosively since 1964 . This market owes its development partly to U.S. monetary policy, in particular to the imposition in 1964 of controls on capital outflows, and partly to the worldwide expansion of the U.S. banking system. To what extent Eurodollar deposits reflect a specific demand for dollar liquidity is unclear; but there are a number of reasons for regarding them as primarily a substitute for foreign holdings of American liquid dollar assets. ${ }^{32}$

Although official (mainly central bank) holdings of Eurodollars have

30. Raymond F. Mikesell and J. Herbert Furth, Foreign Dollar Balances and the International Role of the Dollar (Columbia University Press for the National Bureau of Economic Research, 1974), p. 17.

31. Ibid., p. 86.

32. See ibid., pp. 29-30, for discussion of this point. 
grown substantially in recent years and have acquired considerable significance in the international monetary system, private holdings still account for the bulk of the Eurodollar market. Actually, this market operates at two levels: an interbank market based largely on interest arbitrage, similar to the federal funds market in the United States, and a market involving nonbank depositors and borrowers. Data on the "gross" size of the Eurodollar market reflect operations on both levels, while figures representing the "net" size are adjusted to exclude the double-counting that results from interbank redepositing. Finally, neither "Euro" nor "dollar" is an accurate designation of the phenomenon. The dollar is only one of several currencies, albeit the major one, in which such external deposits are denominated and, furthermore, "the dollar and nondollar components of the Eurocurrency market are in effect all part of the same market." ${ }^{33}$ Nor is the market any longer entirely European; in recent years banks outside Europe have become significant participants.

As Table 4 indicates, the Eurocurrency market, whether measured in gross or in net terms, has been growing at a rapid and accelerating pace since 1964, with a particularly large spurt since 1971. By the end of 1973 the $\$ 155$ billion of net Eurocurrency deposits was larger than the money supply of any country except the United States (although they are not counted in the money supply of any country). Far from inhibiting this expansion, the upheavals in foreign exchange markets since 1971 have spurred it. In fact, in 1971 and again in 1973, Eurodollars were borrowed in substantial amounts to acquire European currencies in anticipation of exchange rate revaluations-that is, to speculate against the dollar! In mid1974, however, the growth of the Eurocurrency market came to an abrupt halt; and the market actually shrank slightly in the third quarter. The reasons for this retrenchment were apparently threefold: a weakening of confidence in the banking system in the wake of several widely publicized bank failures; concern on the part of the banks themselves about basing longer-term loans on short-term and possibly volatile deposits, many of them originating in the oil revenues of the OPEC countries; and some shift in the flow of OPEC funds away from the Eurocurrency market into various national money markets.

Probably more relevant to the international position of the dollar than the absolute size and growth of the Eurocurrency market is the proportion

33. Ibid., p. 28. 
Table 4. Estimated Size of the Eurocurrency Market in Thirteen Countries, 1964-74 ${ }^{\mathrm{a}}$

\begin{tabular}{cccc}
\hline & $\begin{array}{c}\text { Size of Eurocurrency market } \\
\text { (billions of dollars) }\end{array}$ & \\
\cline { 2 - 3 } Year $^{\mathbf{b}}$ & Gross & Net & $\begin{array}{c}\text { Eurodollars as percent } \\
\text { of net market }\end{array}$ \\
\hline 1964 & 20 & 14 & 83 \\
1965 & 24 & 17 & 84 \\
1966 & 29 & 21 & 83 \\
1967 & 36 & 25 & 84 \\
1968 & 50 & 34 & 82 \\
1969 & 85 & 50 & 84 \\
1970 & 110 & 65 & 81 \\
1971 & 145 & 80 & 76 \\
1972 & 195 & 105 & 78 \\
1973 & 295 & 155 & 72 \\
1974 & 330 & 170 & $75^{\mathrm{d}}$ \\
\hline
\end{tabular}

Sources: Morgan Guaranty Trust Company of New York, World Financial Markets, July 16, 1974, p. 4, except the last column, 1964-73, which is from private correspondence with Morgan Guaranty Trust Company, June 4, 1974.

a. The thirteen countries, which represent the principal Eurocurrency market centers, are West Germany, France, Italy, United Kingdom, Belgium, Luxembourg, Netherlands, Switzerland, Sweden, Bahamas, Canada, Japan, and Singapore. These estimates are more inclusive than those of the Bank for International Settlements, which are based on the Eurocurrency business of banks only in the nine European countries listed.

b. Data are for the end of the period, except 1974, which is for March.

c. Gross amounts include a market based on interest arbitrage and one involving nonbank depositors and borrowers. Net amounts are adjusted to exclude double-counting from interbank redepositing.

d. Percent of gross liabilities (approximation).

of that market accounted for by dollars. After maintaining a steady share of between 82 and 84 percent from 1964 to 1969, the dollar component declined to about 72 percent at the end of 1973, recovering to 75 percent in the first quarter of 1974. The most important nondollar currencies in the market were the Deutsche mark, which accounted for more than half the nondollar share at the end of 1973, and the Swiss franc, which accounted for a third. ${ }^{34}$

Three factors relating to the international monetary system apparently accounted for the declining share of the dollar in the Eurocurrency market. One is simply the arithmetic of the dollar depreciations of 1971 and 1973; in the latter year, "roughly $\$ 10$ billion and $\$ 5$ billion of the increases in the estimated gross and net non-dollar components, respectively, simply reflect increases in the dollar equivalent of deposits in these currencies due to

34. Morgan Guaranty Trust Company of New York, World Financial Markets, April 23,1974, p. 8. 
exchange-rate changes." The proliferation of "exchange restrictions and capital controls against the placement of funds by foreigners in European domestic markets" also stimulated the rapid expansion of nondollar Eurocurrency liabilities ${ }^{35}$ Finally, some diversification of both assets and liabilities doubtless resulted from efforts of participants in international markets to hedge against exchange rate changes between the dollar and other major currencies.

A little more than a decade ago, Charles Kindleberger suggested that the integration of long-term capital markets in Europe was taking place not directly but indirectly, via the United States. ${ }^{36} \mathrm{He}$ predicted, further, that this trend would continue, but with the Euromarket taking the place of the New York bond market. This is precisely what has happened. The introduction of U.S. capital controls in 1964 closed the New York market to most foreign borrowers, but the then-embryonic Eurobond market offered an alternative source of dollar-denominated bonds. Although dwarfed by the Eurocurrency market, total Eurobond issues expanded substantially, if irregularly, from $\$ 1.7$ billion in 1966 to $\$ 6.3$ billion in 1972. In 1973, under the pressure of high interest rates, proliferating capital controls, and general uncertainty, Eurobond issues shrank substantially, with much of the activity shifting into longer-term Eurobank credits. These trends continued into early 1974, against the background of elimination of the U.S. capital controls and substantial liberalization of those in other major countries. After mid-1974, however, the volume of longer-term Eurocredits also declined, for reasons described earlier.

As is the case with the Eurocurrency market, the dollar is the major currency of denomination for Eurobonds but, again, the dollar-denominated portion has diminished since 1967, as indicated in the last two lines of Table 5. Concomitantly, the shares of the Deutsche mark and the Swiss franc in Eurobond issues have increased substantially.

A general overview of changes in the composition of world private liquidity between 1964 and 1973 is given in Table 6, although the data on Eurocurrencies there are less comprehensive than those in Table $4 .{ }^{37}$ The share

35. Ibid.

$\rightarrow$ Charles P. Kindleberger, "European Economic Integration and the Development of a Single Financial Center for Long-Term Capital," Weltwirtschaftliches Archiv, Vol. 90 (July 1963), pp. 189-210.

37. The International Monetary Fund, like the Bank for International Settlements, bases its estimates on the Eurocurrency business of banks only in the nine European countries listed in note $a$ to Table 4 . 


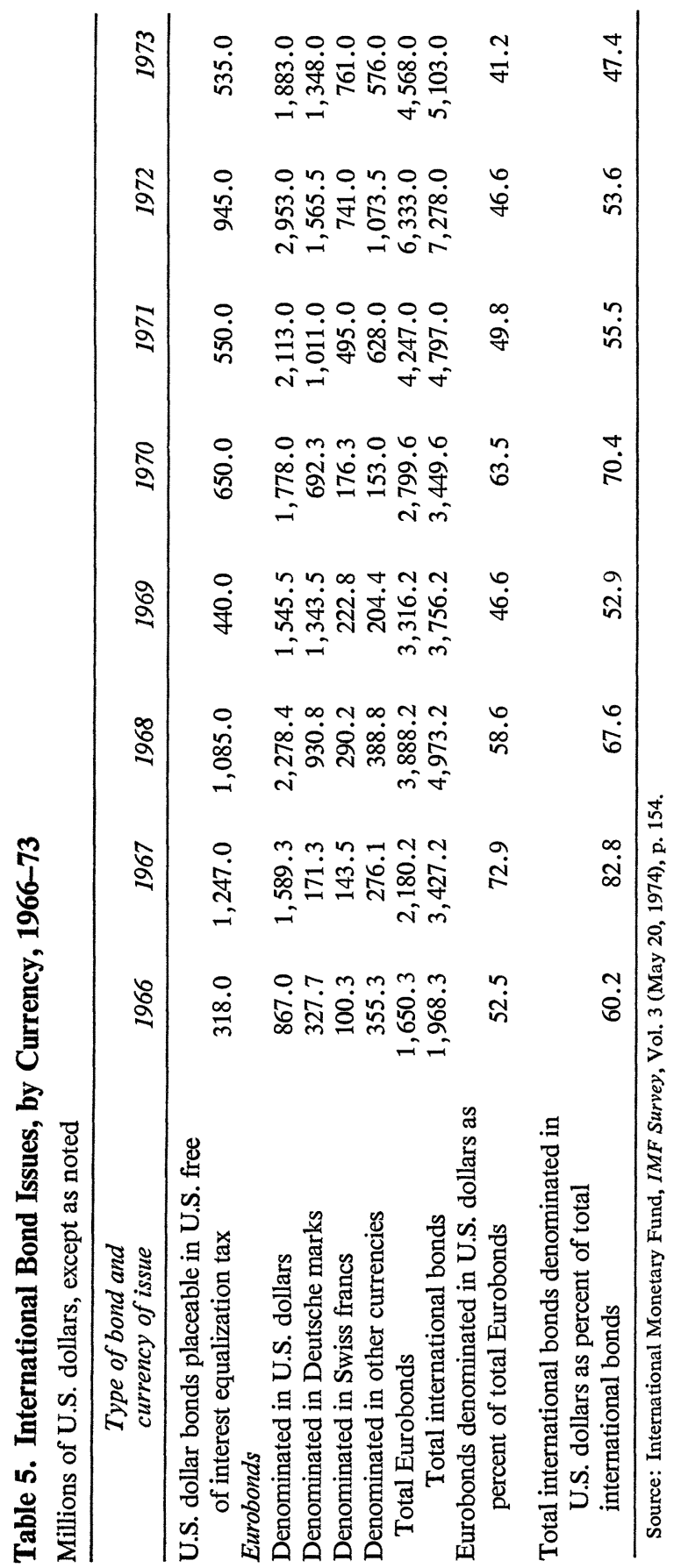




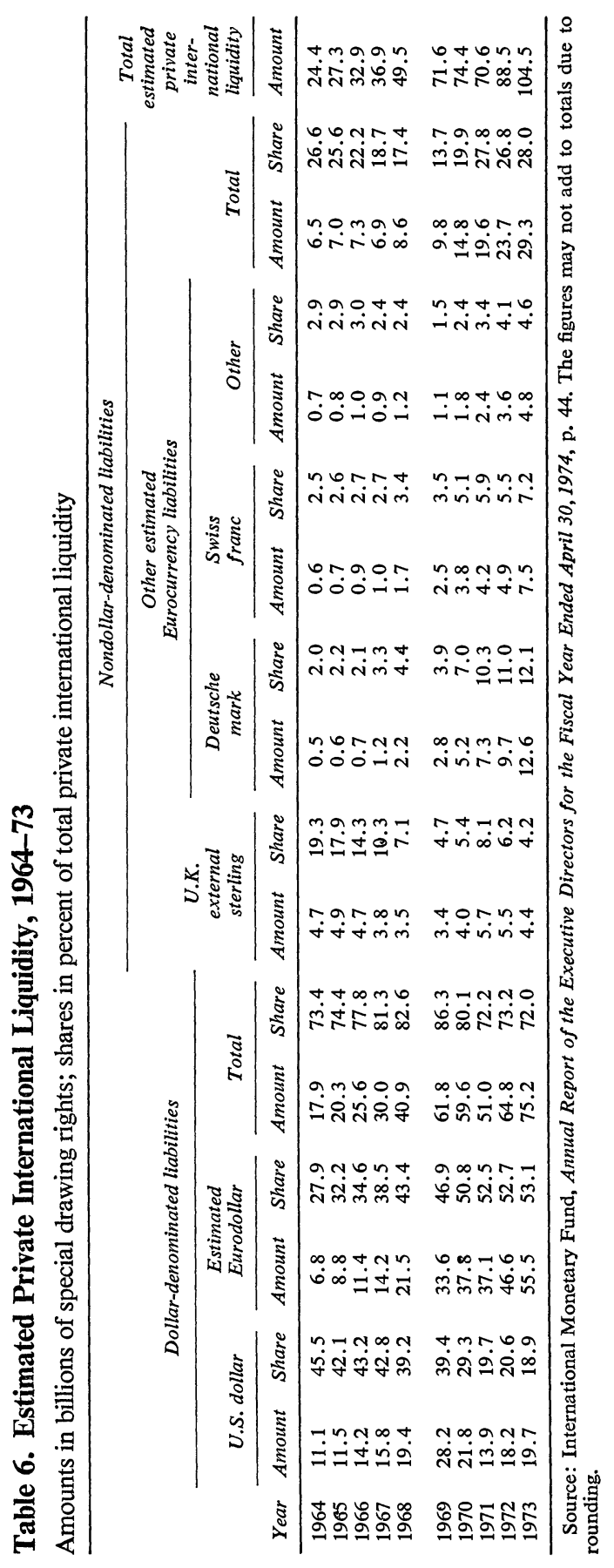


of world private liquidity accounted for by direct liabilities of U.S. residents, which ranged between 39 and 45 percent during 1964-69, fell sharply thereafter; meanwhile, the share of liquid Eurodollar assets rose as they were substituted for liquid American dollar assets. As long as the absolute amount of liquid liabilities of U.S. residents rose, so did the combined share of American and Eurodollar liabilities. After 1969, when direct U.S. liabilities declined in absolute as well as relative terms, the share of total dollar-denominated liabilities also dropped. While this shifting composition of private international liquidity was due initially to repayments by U.S. banks of large borrowings from their foreign branches in 1968-69, it also came to reflect the monetary events since 1970 , which weakened confidence in the dollar and evoked new interest in strong European currencies. Nonetheless, dollar-denominated assets still accounted for nearly three-fourths of total private liquidity in 1973.

\section{THE DOLLAR'S ROLE IN OFFICIAL TRANSACTIONS}

In the official-as opposed to the private-aspects of its key currency role, the dollar remained essentially unchallenged throughout the life of the Bretton Woods system. It was the unit of account in which the par values of the currencies of all IMF member countries were defined. True, because the yardstick was not simply the U.S. dollar but the "gold dollar"- that is, a dollar of a given gold content-there was an inherent ambiguity in the numeraire. ${ }^{38}$ But not until the gold content of the dollar was altered in the Smithsonian Agreement did this aspect of the dollar's role come into question. With the exception of a few countries that maintained the longstanding post-colonial relationships of the sterling area and the franc zone, the dollar was also the universal instrument of exchange market intervention. Finally, it was the predominant reserve currency and the primary source of international reserve growth.

The erosion of the dollar as a unit of account began gradually after the events of mid-1971. The concept of effective changes in exchange rates, defined not simply in terms of the dollar but in terms of a trade-weighted average of partner countries' currencies, was introduced into the inter-

38. Article IV of the Articles of Agreement of the International Monetary Fund stipulates that par values are to be expressed "in terms of gold as a common denominator or in terms of the United States dollar of the weight and fineness in effect on July 1, 1944." 
national lexicon. Symbolically, the International Monetary Fund, which had always defined par values in terms of U.S. dollars (as well as gold content), began in June 1972 to express them also in units per SDR; at about the same time, it also began valuing reserve holdings and other financial data in SDRs. But, as long as the SDR was defined solely in terms of monetary gold, it was an unwieldy and awkward yardstick. It was not until the interim agreement of June 1974, adopting the standard-basket technique for the valuation of the SDR (described above) that a genuine alternative to the dollar as the international unit of account became available. ${ }^{39}$

The first serious challenge to the dollar's virtually exclusive position as an intervention currency came as part of the efforts by the European Economic Community at monetary integration. In order to implement the so-called "snake-in-the-tunnel" policy, introduced early in 1972, to halve the permitted range of variation between any two EEC currencies, the community introduced a complex system of multicurrency intervention. Although the total amount of official intervention in exchange markets since the advent of floating rates has been substantial-for March 1973March 1974 it was estimated at more than $\$ 35$ billion, probably surpassing the amount in any similar period under fixed rates ${ }^{40}$-how much of it was in forms other than traditional dollar intervention is not known. Probably the relative importance of nondollar intervention and the number of countries participating in the EEC snake are directly related. If so, nondollar intervention must have begun to erode very shortly after it began. Great Britain was the first casualty, dropping out of the snake at the time of the sterling crisis in June 1972. Italy followed in February 1973, and a year later so did France, leaving only Germany and six smaller countries as participants in the joint float and the multicurrency intervention system.

Despite the alternatives to dollar intervention offered by the Committee of Twenty, and discussed above, the sparse indirect evidence indicates that any reduction in the dollar's position as the universal intervention currency has been at most marginal. Any alternative system, furthermore, would

39. For a discussion of how the value of the SDR is to be calculated under the new system and a listing of the sixteen countries included in the basket and their weights, see IMF Survey (June 17, 1974), pp. 177, 185. The weight of the dollar in the SDR basket33 percent-far exceeds the average U.S. share of world exports in 1968-72. This excess reflects the continued importance of the dollar in nontrade transactions.

40. Richard A. Debs, "Inflation and the Economic Outlook," Federal Reserve Bank of New York, Monthly Review, Vol. 56 (April 1974), p. 87. 
have to overcome the very substantial margin of efficiency, convenience, and simplicity enjoyed by the mechanism of dollar intervention. ${ }^{41}$

The U.S. dollar has dominated international reserve growth throughout the postwar period. Eighty percent of the growth since 1950 has been in the foreign exchange component, and most of this is in dollars. Furthermore, during the "reserve explosion" of 1970-72, when world reserves roughly doubled, nearly two-thirds of the increase was in the form of direct official claims on the United States (see Table 7). During this period, dollar reserve holdings became more a function of supply than of demand; much of the rise in central bank holdings of dollars was doubtless undesired, at least by the major surplus countries, and reflected the accelerating deterioration of the U.S. international payments position. This was an important change. Despite protestations to the contrary, official dollar holdings were probably largely voluntary until the end of 1969; as late as the second half of that year, in fact, Germany and several other European countries sold gold to the United States to replenish dollar reserves drawn down by borrowings of U.S. commercial banks from the Eurodollar market. ${ }^{42}$

The reserve explosion slowed dramatically in 1973, despite the fact that "there is not as yet any statistical evidence of a reduction in the utilization of reserves by countries that have allowed their currencies to float." 43 Furthermore, although direct claims on the United States remained the single most important source of change in 1973, their importance diminished substantially, accounting for less than one-third of total additions to reserves from transactions (that is, excluding valuation changes). In addition, the importance of dollar-denominated assets in total reserves was reduced by the devaluations of the dollar against SDRs in 1971 and 1973 (see the line "correction for effect of valuation" in Table 7).

Although direct claims on the United States are still the largest single form of official reserves and account for more than half of official holdings of foreign exchange, their share is shrinking with the trend toward diversification of reserve holdings, particularly into Eurodollars. Identified Eurodollar holdings represented almost two-fifths of foreign exchange holdings other than direct claims on the United States at the end of 1973, and "this

41. For a discussion of the advantages of dollar intervention, see F. Boyer de la Giroday, Myths and Reality in the Development of International Monetary Affairs, Essays in International Finance 105 (Princeton University, International Finance Section, 1974).

42. Mikesell and Furth, Foreign Dollar Balances, p. 94.

43. International Monetary Fund, Annual Report of the Executive Directors for the Fiscal Year Ended April 30, 1974, p. 39. 


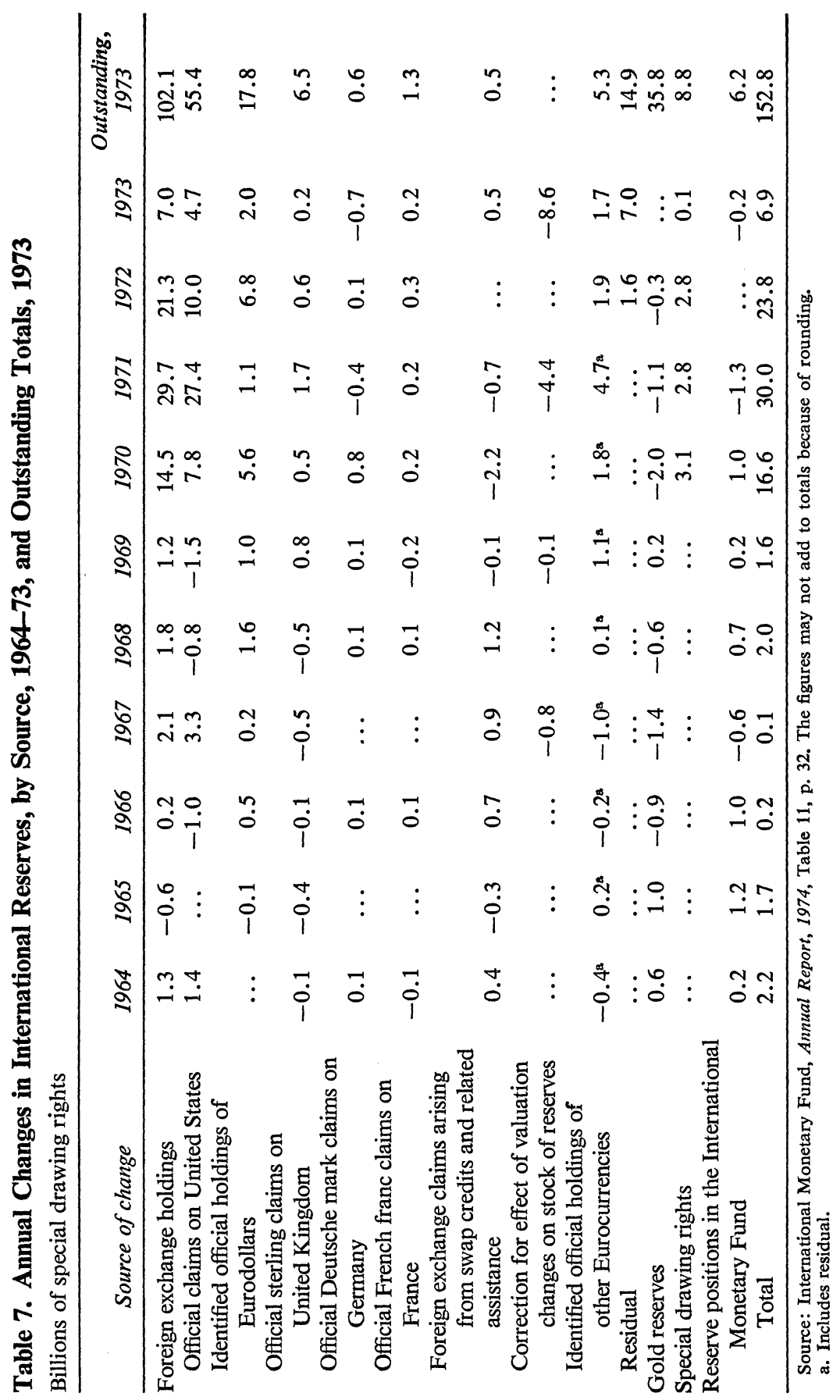


proportion could actually be much higher, depending on [the assumption made about] what part of the unidentified residual ... may consist of Eurodollar holdings." 44 This means that dollar-denominated assets accounted for a minimum of 73 percent of all foreign exchange reserve holdings as of the end of 1973, and for at least 48 percent of international reserves in all forms.

Most of the growth of nondollar foreign exchange reserves has been in the "new" or nontraditional reserve currencies, primarily the Deutsche mark. IMF staff estimates indicate that the share of such currencies "increased from 5 per cent or 6 per cent in 1964 to about double that figure at the time of the advent of widespread floating. The percentage increased by a further 4 per cent or so during the remainder of 1973, which represents an acceleration in the rate at which reserves were diversified." 45 The data in Table 7 show that such holdings may have equaled as much as SDR 22.6 billion, or 22 percent of total foreign exchange reserve holdings, at the end of $1973 .{ }^{46}$

Despite the more rapid diversification of recent years, dollar-denominated assets remain dominant in international reserves. Diversification appears to be the logical concomitant of a tendency for countries to base their exchange rate policies on effective rather than dollar exchange rates, and would undoubtedly be stimulated by the wide adoption of multicurrency intervention like that described in the Outline of Reform. At the same time, "exchange rate flexibility is likely to decrease countries' ability to diversify their foreign exchange holdings in the short run. ..."47 Thus, the full extent of countries' desires to shift the composition of their reserves away from dollar assets into those denominated in other currencies or in a composite unit of account such as the SDR remains to be seen.

\section{The Key Currency Characteristics of the Dollar}

The probable future role of the dollar as a key currency depends on (1) the characteristics desirable in a vehicle currency; (2) the extent to which

44. Ibid., p. 36. Also see Table 7 above.

45. John Williamson, "Increased Flexibility and International Liquidity" (paper presented at the Williamsburg Conference of the Bürgenstock Group, May 1974; processed), p. 11.

46. This figure is an upper limit inasmuch as it assumes that none of the residual amount shown in the table is denominated in dollars or pounds sterling.

47. Williamson, "Increased Flexibility," p. 11. 
the U.S. dollar has-and will have-these characteristics; and (3) possible alternatives to the dollar.

The characteristics that determine the desirability of a vehicle currency fall into two broad groups: those relating to its convenience for exchange or transactions and those affecting stability of asset value, or "capital certainty." 48 A currency possesses exchange convenience when it is broadly acceptable and its use incurs low transactions costs. These characteristics depend largely on the economic size of the issuing country; the depth, breadth, and resiliency of its domestic capital markets; and the absence of trade and exchange controls. By affecting the liquidity of a currency, these characteristics also influence its capital certainty. But capital certainty depends more fundamentally on the maintenance of international purchasing power-that is, stability relative to some average price level of other currencies. ${ }^{49}$

In terms of transactions convenience, the dollar remains about as appealing as it was throughout the Bretton Woods period. The United States still accounts for the largest single share of international trade and the dollar continues to be the most important currency in invoicing of foreign trade. Furthermore, if anything, the role of the United States in capital transactions appears to have expanded. Although the domestic money supplies of many leading industrialized countries have grown faster than that of the United States in recent years, the stock of U.S. dollars and Eurodollars combined has more than kept pace with the stocks of other major currencies. Finally, the U.S. market for domestic securities is still much broader than any other. The total (dollar equivalent) value of security issues in the U.S. market in the early 1970s was several times as large as the total in the next two most important domestic markets, those in Japan (where transactions by foreigners are severely restricted) and in West Germany. ${ }^{50}$

These characteristics of the dollar should, according to economic theory, be reflected in the foreign exchange market: relative to other currencies, the dollar should account for more foreign exchange business; the volume of dollars that can be traded against a particular currency without affecting quoted rates should be greater; the spread between buying and selling rates

48. See, in addition to Cohen, Future of Sterling, Alexander Swoboda, "Vehicle Currencies and the Foreign Exchange Market: The Case of the Dollar," in Robert Z. Aliber (ed.), The International Market for Foreign Exchange (Praeger, 1969), pp. 30-40. 49. Ibid., p. 34.

50. Organisation for Economic Co-operation and Development, Financial Statistics, relevant issues. 
Table 8. Changes in Effective Exchange Rates for Major Currencies, Selected Periods, 1971-74a

Percent, based on pre-June 1970 parities

\begin{tabular}{lccc}
\hline \multicolumn{1}{c}{ Currency } & $\begin{array}{c}\text { Dec. 18, 1971- } \\
\text { July 6, 1973 }\end{array}$ & $\begin{array}{c}\text { July 6, 1973- } \\
\text { Jan. 23, 1974 }\end{array}$ & $\begin{array}{c}\text { Jan. 23, 1974- } \\
\text { May 13, 1974 }\end{array}$ \\
\hline U.S. dollar & -12.10 & 11.39 & -8.93 \\
Canadian dollar & -3.20 & 4.35 & 0.57 \\
Japanese yen & 9.91 & -11.09 & 5.76 \\
British pound & -19.74 & -2.55 & -0.13 \\
German mark & 19.01 & -6.92 & 6.60 \\
French franc & 6.15 & -10.66 & -4.69 \\
Italian lira & -24.93 & 5.40 & -4.04 \\
Dutch guilder & 1.75 & 2.76 & 4.12 \\
Belgian franc & 2.20 & -2.98 & 3.77 \\
Swiss franc & 16.14 & -4.98 & 6.26 \\
\hline
\end{tabular}

Sources: Columns 1 and 2-Morgan Guaranty Trust Company of New York, World Financial Markets, April 23, 1974, p. 2; Column 3-calculated from daily data sheets issued by Morgan Guaranty Trust Company during the period January 23 to May 13, 1974.

a. Percentage exchange rate changes vis-à-vis a group of fourteen major countries, weighted according to bilateral trade.

should be narrower for dollars; brokers' fees should be lower for dollar transactions; and forward contracts should be easier to arrange in dollars. Writing in the late sixties, Swoboda collected quantitative evidence that supported these points; 51 and piecemeal and impressionistic evidence on the current functioning of the foreign exchange markets indicates that they still hold true. ${ }^{52}$ With the abolition early in 1974 of U.S. capital controls, the dollar became the only major currency free of any form of exchange controls, a development that enhanced its exchange convenience relative to other currencies.

On the other hand, the dollar has lost some of its appeal as a guarantor of asset certainty. Under the Bretton Woods system, the dollar was the best available store of purchasing power over foreign exchange in general, for two major reasons. First, its potential fluctuation around parity against another currency was only half as wide as that involving two nondollar currencies. Second, because of the $n$ th-country role, a change in its parity was viewed as much less likely than changes for other currencies.

51. Swoboda, "Vehicle Currencies," pp. 35-39.

52. See How Well Are Fluctuating Exchange Rates Working? Hearings before the Subcommittee on International Economics of the Joint Economic Committee, 93 Cong. 1 sess. (1973). Similar comments were made both orally and in private papers circulated at the Williamsburg conference cited in note 45 above. 
All of this has changed dramatically since 1969. In each of the two most recent periods reported in Table 8, the dollar sustained the greatest percentage change in the effective exchange rate among the ten currencies listed. Furthermore, as the United States entered the era of double-digit inflation, fears arose about further deterioration in the value of the dollar vis-à-vis the currencies of countries with lower rates of inflation-in particular, the Deutsche mark.

There is, however, a strong argument for regarding the relatively large fluctuations of the dollar in part as a transitional phenomenon, a temporary divergence between the stock and flow equilibria resulting from a prolonged period of disequilibrium. ${ }^{53}$ Once the desired shift in the composition of reserve assets, both official and private, is completed, a major cause of volatility in the valuation of the dollar vis-à-vis other currencies should disappear, unless some new disturbance causes another dramatic shift in the desired composition. ${ }^{54}$ And a smoothly functioning mechanism for international payments adjustment should forestall a renewed divergence between stock and flow equilibrium in the foreign exchange markets.

\section{THE POLITICAL DIMENSIONS OF A KEY CURRENCY ROLE}

So far, this discussion has concerned the economic factors that impinge on the dollar's role as a key or vehicle currency. But its acceptability in this role depends on the preferences not only of private entities but also of central bankers, who are heavily influenced by political as well as economic considerations. From the point of view of participants in other countries, the benefits from a key currency system accrue primarily in the efficiency associated with integrated markets and in the existence of international money. The costs are perceived primarily as the greater vulnerability to economic developments and policies in the key currency country, and therefore, a loss of control over the domestic economy.

This interdependence is felt most acutely in the domestic monetary policy of non-key currency countries. "Flows of [Eurodollar] funds into and out

53. See Walter S. Salant, "The Post-Devaluation Weakness of the Dollar," BPEA (2:1973), pp. 481-96.

54. Indeed, the demand for dollars to make oil payments appears already to have reduced substantially the magnitude of the "dollar overhang" problem in the eyes of other industrialized countries. 
of the market across currency borders influence the respective rates of growth of money and credit of countries so affected-with the exception of the United States itself." 55 And, while the extent to which foreign monetary authorities can offset or sterilize the impact of such currency flows on their own money supplies is uncertain, their efforts to induce monetary restraint undoubtedly have been at least partially frustrated by inflows of funds from abroad.

The major channel for transmitting external influences is the Eurodollar market. "The euro-dollar market is more than an appendage to the New York money market, but the linkage is very close and the degree of independence of the euro-dollar market from New York is limited."56 One reason for the close linkage is the dominant position of U.S.-owned banks in the Eurocurrency market. The share of Eurocurrency deposits in London held in foreign branches of American banks rose from 24 percent at the end of 1963 to a peak of 54 percent at the end of 1969. It then dropped off to 43 percent by the end of 1972 , presumably reflecting the growing importance of non-U.S. participants in the market and of Eurodeposits denominated in currencies other than dollars. ${ }^{57}$ There is also some evidence that, since the repayment in 1970 and 1971 of large borrowings by U.S. banks from the Eurodollar market, foreign loan demand, and therefore foreign money market conditions and regulations affecting Eurodollar borrowing, has become a more important factor in Eurodollar rates. ${ }^{58}$

Traditionally, the integration of national markets has rested on dependence rather than interdependence: a one-way relationship in which the United States was effectively immune from outside influences. In his study of the international transmission of wage inflation over the period 1956-71, Nordhaus concluded that the United States exerted a powerful influence on prices abroad because it "is the only country that does not (or can afford not to) care seriously about the effect of its price level on its external position." 59 Similarly, over the period 1953-71 "inflows from abroad have not played a significant rôle in weakening the impact of monetary restraint

55. Geoffrey Bell, The Euro-Dollar Market and the International Financial System (John Wiley, 1973), p. 42.

56. Ibid., p. 64.

57. Bank of England, Quarterly Bulletin, Vol. 10 (March 1970), p. 48; Vol. 13 (March 1973), Tables 8(1), 8(8); and various intervening issues.

58. Mikesell and Furth, Foreign Dollar Balances, pp. 76-77.

59. William D. Nordhaus, "The Worldwide Wage Explosion," BPEA (2:1972), p. 459. 
Table 9. Ownership of U.S. Gross Public Debt, 1958-73

Dollar amounts in billions

\begin{tabular}{|c|c|c|c|c|c|}
\hline \multirow[b]{2}{*}{ Year $^{\mathrm{a}}$} & \multirow[b]{2}{*}{ Total } & \multirow{2}{*}{$\begin{array}{l}\text { Held by } \\
\text { private } \\
\text { investors }\end{array}$} & \multicolumn{3}{|c|}{ Held by foreign and international investors } \\
\hline & & & Amount & $\begin{array}{c}\text { As percent } \\
\text { of total }\end{array}$ & $\begin{array}{l}\text { As percent } \\
\text { of private }\end{array}$ \\
\hline 1958 & $\$ 283.0$ & $\$ 202.3$ & $\$ 7.7$ & 2.7 & 3.8 \\
\hline 1959 & 290.9 & 210.6 & 12.0 & 4.1 & 5.7 \\
\hline 1960 & 290.2 & 210.0 & 13.0 & 4.5 & 6.2 \\
\hline 1961 & 296.2 & 214.8 & 13.4 & 4.5 & 6.2 \\
\hline 1962 & 303.5 & 219.5 & 15.3 & 5.0 & 7.0 \\
\hline 1963 & 309.3 & 220.5 & 15.9 & 5.1 & 7.2 \\
\hline 1964 & 317.9 & 222.5 & 16.7 & 5.3 & 7.5 \\
\hline 1965 & 320.9 & 220.5 & 16.7 & 5.2 & 7.6 \\
\hline 1966 & 329.3 & 219.2 & 14.5 & 4.4 & 6.6 \\
\hline 1967 & 344.7 & 222.7 & 15.8 & 4.6 & 7.1 \\
\hline 1968 & 358.0 & 228.5 & 14.3 & 4.0 & 6.3 \\
\hline 1969 & 368.2 & 222.0 & 11.2 & 3.0 & 5.0 \\
\hline 1970 & 389.2 & 229.9 & 20.6 & 5.3 & 9.0 \\
\hline 1971 & 424.1 & 247.9 & 46.9 & 11.1 & 18.9 \\
\hline 1972 & 449.3 & 262.5 & 55.3 & 12.3 & 21.1 \\
\hline 1973 & 469.9 & 261.7 & 55.6 & 11.8 & 21.2 \\
\hline
\end{tabular}

Source: Federal Reserve Bulletin, various issues.

a. End of period.

[in the United States]," ${ }^{60}$ while capital flows arising from developments and policies in the United States do at times interfere with monetary policy in other countries.

In the 1970s, however, the United States has increasingly become a partner in two-way interdependence. The increasing share of the foreign sector in the U.S. economy and the major role of external factors, including the effective depreciation of the dollar, in the acceleration of U.S. inflation in 1973 have already been discussed. In the financial sphere, the most important exposure of U.S. markets to influences from abroad has come through the dramatic increase in foreign ownership of the U.S. public debt, revealed in Table 9. The massive accumulations of dollars by foreign central banks during the monetary turmoil of 1971-73 meant that some 70 percent of the estimated total unified-budget deficit of $\$ 66$ billion incurred by the federal government in that period was financed by foreigners, and more

60. Warren D. McClam, "Credit Substitution and the Euro-Currency Market," Banca Nazionale del Lavoro Quarterly Review, No. 103 (December 1972), p. 330. 
than 75 percent of the estimated $\$ 30$ billion increase in marketable debt outstanding was acquired by foreign holders. ${ }^{61}$ Even though econometric evidence suggests that, prior to 1972, changes in foreign central bank holdings of Treasury bills had only small, short-term effects on Treasury bill rates, ${ }^{62}$ foreign ownership of such a substantial portion of the public debt cannot help but expose this important segment of U.S. financial markets to external influences.

A substantial literature has alleged that the United States has derived "seignorage" benefits from its key currency status, enabling it to finance a payments deficit at a cost below the true or competitive rate of interest. In fact, however, both private and official foreigners hold dollar balances in interest-bearing form, and the competitiveness and financial sophistication that characterize the international money market make it highly unlikely that even the U.S. government can exercise the monopolistic exploitation involved in seignorage. ${ }^{63}$ Although the interest rates paid on Treasury bills are lower than rates of return on real capital, this advantage is more accurately regarded as a liquidity premium than as a seignorage profit. Ironically, one period during which the United States may have garnered seignorage gains was 1971-73, when the major purchases of U.S. government securities by foreigners doubtless held down the cost of financing the U.S. deficit. But this was a special circumstance associated with a period of breakdown and transition, rather than a characteristic of a smoothly functioning key currency system. ${ }^{64}$

Seignorage gains aside, the broader issue is whether the special role played by the dollar under the Bretton Woods system reinforced or com-

61. Richard V. Adams, "Foreign Activity in United States Treasury Securities in Fiscal Years 1971-1973," in Issues in Federal Debt Management, Proceedings of a Conference Sponsored by the Federal Reserve Bank of Boston, June 1973 (FRBB, no date), p. 195.

62. Thomas D. Willett, "Discussion" (of Adams' paper) in Issues in Federal Debt Management, pp. 201-02.

63. See Ronald I. McKinnon, Private and Official International Money: The Case for the Dollar, Essays in International Finance 74 (Princeton University, International Finance Section, 1969), pp. 21-23.

64. The lure of these earnings was undoubtedly a major stimulus to the Eurodollar market, and its growth has served to bid down monopoly rents in both the European and the American banking systems. There is an important distinction between seignorage and the additional earnings derived from performing international banking and financial services, which are indeed a benefit conferred by the key currency function. 
promised the freedom of the United States to pursue domestic economic targets. A related question was whether the greater flexibility in domestic policy that was afforded by the ability to postpone adjustment of payments imbalances-if, indeed, it existed-was exercised to the detriment of other countries and of the international monetary system itself. This complex and still unsettled issue will not be recapitulated here; in any case, I believe it is largely irrelevant to the future international monetary system, for two reasons. First, by universal agreement, the rules of the future international monetary system - whatever its precise nature and the dollar's role in itwill not permit the protracted and cumulative disequilibria in external positions that characterized the Bretton Woods system. Second, the deepening vulnerability of the United States to external disturbances raises its stake in maintaining a smoothly functioning international monetary system.

\section{Present Realities and Prognosis for the System}

The simple taxonomy given at the beginning of this paper encompasses three kinds of mechanisms for ensuring the consistency of the international monetary system: one operates under universal automatic rules, such as the gold standard or freely floating exchange rates; the second under agreed rules and a supranational authority; and the third with a key currency.

Although the present system is frequently described as one of floating exchange rates, it actually falls within none of these three classifications. Rather, it is a system in transition, without clearly defined rules, operating with "probably the widest combination of exchange systems ever with the exception perhaps of the 1930's," in the words of an IMF official. As of June 1973, this same official noted,

we have 10 countries floating with different degrees of intervention; we have 8 countries floating as a bloc, maintaining a very close relationship among themselves, but with no obligation whatsoever to defend a rate with respect to the dollar; and we have 24 countries that have pegged their currencies with respect to the dollar; 14 with respect to the French franc; and 11 with respect to the pound; and we have 53 other countries that have either declared central rates or par value which they defend by intervening in any of the 3 above-mentioned currencies. $^{65}$

65. Statement of Ricardo H. Arriazu, Alternate Executive Director, International Monetary Fund, in How Well Are Fluctuating Exchange Rates Working? p. 107. See also Economic Report of the President, February 1974, Table 53, p. 197. 
As this brief summary suggests, the present system is marked by active and, to a considerable extent, uncoordinated behavior by national governments and central banks. Yet with respect to direct intervention in foreign exchange markets, there has apparently been considerable consultation, at least to avoid working at cross-purposes and to provide intermittent mutual support. Rather, the failure to coordinate has been demonstrated in "indirect" intervention: central bank or government activities undertaken to modify or restrict the behavior of the foreign exchange markets.

One form of indirect intervention by which countries may seek to minimize losses of reserves or, alternatively, depreciation of their currencies is foreign (as opposed to domestic) borrowing by governmental or government-related authorities. France, Italy, the United Kingdom, and Japan were among the countries that used this technique, primarily in the Eurodollar market, to strengthen their payments positions in late 1973 and early 1974.

The time-honored method of modifying exchange rate or reserve positions is some form of direct controls on trade, investment, or financial transactions or, sometimes, all three. The period since August 15, 1971, has witnessed escalation of controls for balance-of-payments purposes, mostly by surplus countries in an effort to limit capital inflows and thus forestall or, more often, restrict appreciation of their currencies. That such controls were apparently ineffective in stemming the inflowing tide of funds did not prevent these countries from applying them in more and more diverse forms and progressively tightening them. ${ }^{66}$

Even during 1973 and the first part of 1974, after the move to "generalized floating," direct restrictions for balance-of-payments or exchange-rate purposes remained in force. The relaxation of restrictions on imports and imposition of taxes or controls on exports were, with a few exceptions, directed at alleviating domestic inflationary pressures or avoiding shortages of scarce commodities rather than at modifying a country's external position. But with the onset of the oil crisis at the end of 1973, liberalization of import restrictions among developed countries tapered off. In a few countries with severe payments problems, the liberalizing moves were in fact reversed; in the most dramatic example, in May 1974, Italy imposed a 50

66. See International Monetary Fund, Annual Report, 1974, pp. 44-46; Economic Report of the President, February 1974, Table 54, pp. 198-99; IMF Survey, Vol. 3 (September 2, 1974), pp. 274-76. 
percent deposit requirement on imports, including those from its Common Market partners.

Such exceptions apart, direct controls aimed at a country's external position continued to be applied primarily to capital account transactions in 1973 and the first part of 1974. Efforts to curb capital inflows were stepped up in many developed countries early in 1973, and were often accompanied by measures liberalizing capital outflows. A major exception to the pattern was Japan which, with an extensive program of exchange controls already in place, emphasized relaxation of controls on both capital outflows and direct foreign investment in Japan. By the latter part of 1973, after the oil embargo, the dominant trend was moderated or even reversed, with many developed countries moving to liberalize capital inflows and, in a few cases, even reintroducing measures to curb capital outflows. Again, there was a major exception: the United States announced liberalizing steps in each of its three capital control programs during 1973; moreover, encouraged by the substantial strengthening of the dollar during the second half of 1973 and by the safety valve that floating exchange rates offered against speculative disasters, it abolished-technically, suspended-all three programs in January 1974.

Monetary reform will obviously follow an evolutionary course, incorporating many of the changes that have taken place in the early seventies; but the preceding paragraphs suggest some of the dangers inherent in simply leaving things as they are. At present most countries behave as if they have explicit current account objectives, and therefore implicit exchange rate targets, rather than as if they are willing to allow exchange rates to move freely to clear the foreign exchange markets. In the situation of late 1973 and the first part of 1974, these objectives led a number of important countries to make liberalizing adjustments; other circumstances, however, would generate pressures toward increased controls, as they did throughout most of 1973 and the years immediately preceding.

Not only are the targets of individual countries generally uncoordinated and therefore likely to be inconsistent, but the recent drastic shifts in the terms of trade between oil-producing and oil-consuming countries make the problem of reconciling them virtually intractable. It was one thing for most industrialized countries to aim for current account surpluses when a surplus for the group as a whole was the natural counterpart of the collective deficit of the developing countries. But it is quite a different matter for individual industrialized countries to aim at surpluses when the group as a 
whole must run a collective deficit as the counterpart of the massive surpluses of the oil producers. ${ }^{67}$ Efforts to use exchange rate policies, whether direct or indirect, to achieve such surpluses can only result in pushing the inevitable deficits around among the oil-consuming countries, and is bound to be self-defeating as well as damaging to the already hard-hit developing countries that lack petroleum or other costly essential commodities. The price of uncoordinated external targets and exchange rate policies has risen sharply.

Under these circumstances, there are strong pressures for the United States to resume some sort of $n$ th-country role, modifying its own current account target in the interest of stabilizing an international system under extreme stress. These pressures are mounting as it becomes clear that the investments fed by the burgeoning surpluses of the oil-producing countries will be concentrated in a few strong-currency countries, the United States probably chief among them. ${ }^{68}$ Unless the United States takes active steps, such capital inflows will bring about appreciation of the dollar and a negative impact on the U.S. current account.

Indeed, there is some question as to whether the United States has actually abandoned its $n$ th-country role. For, despite this country's insistence on symmetry of the adjustment mechanism and on its own freedom of action on exchange rates in a reformed international monetary system, and despite the Federal Reserve's commitment in principle to exchange rate intervention under certain conditions, actual intervention by the United States has been limited. Apart from the two official devaluations of the dollar, the United States remains, as it was under the Bretton Woods system, "largely passive as to its exchange rates." 69 Were it to desert this

67. The industrial countries as a group experienced a decline in their reserves during 1973. See International Monetary Fund, Annual Report, 1974, p. 37.

68. Of the estimated $\$ 25$ billion to $\$ 28$ billion surplus accumulated by the OPEC countries during the first eight months of 1974 , the U.S. Treasury estimates that some $\$ 7$ billion has been invested in the United States, with the bulk of the remainder currently held in the form of short-term Eurocurrency deposits. See "The Financial and Economic Consequences of the Quadrupling of the Price of Oil," submission to the Senate Permanent Subcommittee on Investigations in conjunction with testimony by Secretary of the Treasury William E. Simon, September 18, 1974, in Department of the Treasury News, W.S.-108 (September 20, 1974), pp. 4-5.

69. Henry C. Wallich, "CXX and After," Finance, Vol. 92 (September 1974), p. 6. Indeed, an active exchange rate policy for the United States is fundamentally incompatible with the continued use of the dollar as a major intervention currency. Hence the recent interest in alternative intervention schemes, described in Annex 3 of the Outline of Reform. 
passivity for active management in order to buttress its current account against the pressures just described, the effect would be greatly to exacerbate the strains imposed on the international monetary system by recent developments in the world economy.

Clearly, the United States cannot undertake an unlimited commitment to passivity under the present circumstances. It could not, for example, tolerate a concerted refusal by other oil-consuming countries to accept any current account deficits whatsoever, which would impose on the United States the entire burden of the counterpart to the projected annual current account surplus of $\$ 60$ billion to $\$ 80$ billion of the oil producers. Even more fundamentally, the United States could not tolerate the fluctuations in unemployment that would result if the $n$ th-country role were to produce wide short-term swings in the current account. Any U.S. commitment would have to be delimited in multilateral negotiation among the oilconsuming countries to establish a framework for balance-of-payments adjustment to the new world petroleum situation. Yet the United States must assume leadership in these negotiations. Any such leadership is almost certain to require of the United States more flexibility and responsibility in adapting its payments situation to the needs of the group than the other oil-consuming participants will be willing (or perhaps able) to undertake.

In summary, then, this argument for the continuation of some key currency role for the dollar, as opposed to the strict symmetry of rights and obligations envisaged in the major reform proposals, reinforces the arguments based on convenience and efficiency discussed in the previous section. At the moment and for the foreseeable future, no substitute on the horizon can match the dollar for transactions convenience or asset liquidity. And, although one can conceive of the dollar continuing in its private international roles even if it dropped out of its official ones, there is considerable complementarity between the two, and governments as well as the private sector reap efficiency gains from the existence of an international money.

The fulfillment of a key currency role requires also a resumption of the dollar's superior performance with respect to inflation-and this is uncertain. But over the long term, the dollar has maintained more stable purchasing power than any other major currency and, despite the aberrations of the past year or two, this relationship is unlikely to be permanently altered. Even more to the point, while the restoration of reasonable stability in the value of the dollar is essential to the successful operation of a modified key currency system, it appears increasingly to be a sine qua non 
for the viability of any international monetary system. The belief that even a symmetrical system of freely fluctuating exchange rates could fully insulate countries from inflationary disturbances, particularly those originating in a major country, is being considerably modified in the light of recent experience.

To foresee, and even to advocate, some form of key currency role for the dollar is by no means to suggest a return to the Bretton Woods system. The need for a prompt and effective adjustment mechanism, most probably in the form of managed exchange rate flexibility with rules for intervention, has already been stressed. Such a process is essential both to avoid the economic strains imposed by prolonged disequilibrium and to give the participants in the international monetary system control, within some range, over the rate at which international reserves are created. At the same time, the replacement of the convertibility mechanisms of the gold standard with a modified form of asset convertibility involving SDRs seems both likely and desirable. Consultations among major countries and agreement to be guided by the International Monetary Fund are likely to be more important in achieving consistency among external objectives than they were under the Bretton Woods system. Finally, the key currency concept is not an all-or-nothing proposition. As the relative importance of other countries in the world economy grows, it is logical that their currencies should acquire some international role; SDRs can also play a useful part in the official key currency functions. ${ }^{70}$

When all this has been said, however, there remains no acceptable alternative to the dollar in all its key currency roles. Moreover, consistency in external targets is unlikely if the United States does not assume some special responsibility for the international monetary system. The appeal to symmetry and the United States' assertion of an active exchange rate policy were essential to pry the international system loose from its prolonged disequilibrium and to restore the nearly paralyzed exchange rate mechanism as an instrument of adjustment. With that task accomplished, the new demands of international political economy and considerations of market efficiency and convenience together suggest that efforts to achieve strict symmetry of rights and obligations should not be pushed too far. It is, of course, inherently difficult to embody legal asymmetry in any document

70. de la Giroday points out in Myths and Reality (p. 10) that at no time since about 1900 has one standard or numeraire had a complete monopoly of the key currency role. See also Cohen, Future of Sterling, Table 1.1, p. 18. 
that requires the formal approval of sovereign states. Given this tension between the legal pressures for symmetry and the economic pressures for asymmetry, ${ }^{71}$ the world might do better to modify its efforts toward a comprehensive formal constitution for the international monetary system in the Bretton Woods mold, in favor of the more informal, piecemeal, evolutionary international monetary constitution that is already taking shape.

71. On this point, see Cooper, "Eurodollars, Reserve Dollars, and Asymmetries," pp. $327,344$. 


\section{Comments and Discussion}

Richard N. Cooper: Marina Whitman has provided an admirable summary of the issues in monetary reform and the changing-or, in her view, relatively unchanging-role of the dollar. My remarks are not so much comments on her paper as questions and observations prompted by reading it.

The first question is, why have controls on international transactions increased in Europe rather than diminished with the introduction of floating exchange rates? A number of continental Europeans warned us this would happen; but some Anglo-Saxons, including myself, said it shouldn't happen (although we didn't say that it wouldn't happen). In fact, except in the United States, controls have been broadened, even if only modestly in some cases.

One might be tempted to say that governments are ignorant and are just making a mistake. But I suggest that this group of controls reflects strong and, to some extent, justified anxieties about the impact of exchange rates on wage inflation. The fear is that a depreciation of the currency will spur an increase in wages and in turn will lead to a further depreciation of the currency through an increase in product prices. The effect is asymmetrical: an appreciating currency will not induce a comparable decrease in wages. The controls are meant to break the inflation cycle of wages-exchange rate-wages.

The second question that comes to mind on reading the paper is, why have floating exchange rates not insulated economies from inflationary impulses from abroad as some advocates said they would? Part of the answer lies in the fact that exchange rates have not floated freely. But in any case I think that the insulating characteristics of floating exchange rates were oversold. First, floating rates cannot insulate economies from real disturbances, as distinguished from monetary disturbances. Many of the 
disturbances causing the inflationary impetus have been real, like the failure of crops and the oil cartel. A second factor is the cash-balance effect. Suppose that, in a world of floating rates, capital flows into country $A$ out of a country $B$ that has an unusually strong monetary expansion. Unless that flow is accompanied by increases in $B$ 's export prices, the monetary disturbance abroad will add to the liquidity of country $A$, if not through an actual capital inflow then through an appreciation of $A$ 's currency which lowers import prices measured in that currency. How important such a cash-balance effect is in quantitative terms is, in my view, an open empirical question. But conceptually it could be a channel for international transmission of purely monetary disturbances even with freely floating rates. A third possible reason why floating exchange rates have not insulated economies from inflationary impulses from abroad is that they may have relaxed the restraint on government spending that was imposed by concern about the balance of payments. Some observers-most of them not professional economists-have long felt that governments are always straining at the bit to increase expenditures, and that they will inflict more inflationary damage with floating exchange rates because they will not be punished by balance-of-payments deficits. The record is consistent with that view, at least to the extent that, in many countries, much of the monetary expansion after 1970 has arisen from domestic credit creation rather than from the growth of international reserves.

A third question is about Whitman's suggestion that the United States should after all play the $n$ th-country role in this period of very large payment flows arising from the increase in oil prices. If Japan and Western European countries are free to set their external targets and if they choose ultimately to pay for their oil with goods (as I would expect) rather than to borrow indefinitely, they would be expanding exports enormously. Let me reinforce the paper's conclusion that we really cannot accept the $\$ 60$ billion to $\$ 80$ billion deficit in U.S. trade implied by this country's assumption of the residual role. I suggest that mercantilist strains would develop in America with a force never seen before. Understandably, American labor in particular would not tolerate the required closing down of major industries. I submit that realism limits the potential scope of the $n$ thcountry role.

I have two other observations. First, the problem of dollar overhang, which several years ago was one of the major issues in international monetary reform, seems now to have vanished. Not that the dollars are fewer, 
but most holders of dollars-Japan, for example-are happy to have them. They will be gradually transferred to OPEC countries, and eventually a new dollar overhang may emerge there. Meanwhile, the attraction of gold as an official monetary medium seems to have faded, as a result partly of this new confidence in dollars and partly of the highly erratic performance of gold prices.

My final comment concerns the question of symmetry in the international monetary system. There is a contradiction between the formal equality of sovereign nations and the actual inequality among them based upon military, political, and economic importance. In formal arrangements, nations declare their sovereign rights and national dignity, and insist on equal treatment. This is especially pertinent in the monetary area and would create tensions in any American-type constitutional convention or any formal Bretton Woods-type reform of the monetary system. As Whitman suggests in her conclusion, it would be better to develop a system informally, in the manner of the British rather than the American constitution. Such an evolutionary process would not confront nations with the need to assert their sovereignty and could reflect a consensus that otherwise would not be possible.

Robert Solomon: Marina Whitman has given us an interesting paper, with a wealth of useful material. But, to be frank, I am unsure about what the real issues are in the question of leadership versus symmetry. "Leadership" implies something more than large arithmetic weight, but the paper tells little about the economic and political aspects of any unique role of the dollar.

Because it forms an important part of the historical background, let me start with a query concerning Whitman's interpretation of the Bretton Woods agreement. She characterizes it as envisaging a symmetrical system. Yet the Articles of Agreement, while specifying that member nations will have an obligation to maintain their exchange rates within 1 percent of their par values, also specifies that "a member [it's in the singular] whose monetary authorities, for the settlement of international transactions, in fact freely buy and sell gold ... shall be deemed to be fulfilling this undertaking" (p. 5). This seems to suggest that the United States would be the $n$th country, at least with respect to intervention in exchange markets. Thus the original concept of Bretton Woods may not have been as symmetrical as the paper suggests. It is also notable that the Bretton Woods agreement 
made no explicit provision for systematic growth of world reserves. I'm too young to know whether the founding fathers expected the dollar to play that role, too.

In any event, whether or not it was envisaged at Bretton Woods, the international monetary system did function in an asymmetrical manner in the postwar period. The United States was the $n$th country in respect to intervention in exchange markets and to concern-or, rather, lack of itabout its overall balance of payments, though the latter asymmetry was not clear-cut. Efforts were made to reduce U.S. deficits, mainly by means that most economists disapprove of. U.S. deficits did make it possible for other countries to satisfy their desires or targets for growing reserves as their economies expanded and as world trade increased. But was the United States also the $n$th country with respect to current-account targets? I'm not at all sure. Significantly, the system broke down only when the surplus in the U.S. current account disappeared. The United States did have a rough current-account target and other countries expected it to have one. This last observation may be a criticism more of Robert Triffin than of Whitman, since it provides an explanation of the so-called inevitable breakdown different from Triffin's.

The postwar monetary system rested on the assumption of an unchanged dollar price of gold, on which other countries relied as they accumulated dollars as reserves. The disappearance of the surplus in the U.S. current account in 1970, combined with the unwillingness of the major surplus countries to appreciate their currencies against the dollar, led to the massive flight from the dollar and the suspension of convertibility on August $15,1971$.

Out of all this came the U.S. proposals for a reformed system that would be symmetrical in most respects. These proposals are well described in the paper, as is the product of the Committee of Twenty and the ambivalence in U.S. positions during the negotiations that led to it. Whether that ambivalence reflected merely negotiating tactics or a secret desire to preserve a reserve-currency role for the dollar or a difference between George Shultz and Paul Volcker is a question that is not easily answered.

The discussion in the paper of the various roles of the dollar in private transactions raises questions. An elaborate table on private international liquidity shows the rise and fall of the share of dollar-denominated liabilities in total liabilities. My reaction is, so what? In fact, I doubt that the concept of private international liquidity has much significance. Does it 
really matter to the system if a Danish businessman decides to hold balances in the Eurodollar market rather than in his own currency in a Danish bank? What advantage, economic or political, does the United States derive from the fact that nearly three-fourths of so-called private international liquidity is in dollar-denominated assets? It seems to me to be relatively unimportant from the viewpoint of leadership.

The most interesting questions arise with respect to the dollar's role in official transactions. To begin with a quibble, I believe it is a mistake to regard the growing use of effective exchange rates (rather than exchange rates expressed in dollars) as a decline in the official role of the dollar. The concept of effective exchange rates represents an advance in economic sophistication that we should all welcome. In the period leading up to the Smithsonian meeting, blood, sweat, and tears had to be shed to make it clear that a country could be devaluing against the world while its currency appreciated against the dollar. Furthermore, I see no connection between the sensible practice of looking at effective exchange rates and the preferences of countries as to the currency in which they hold their reserves.

With respect to the official role of the dollar, the major issues are a blend of economic and political considerations and influences. U.S. monetary policy can undermine anti-inflationary policies in other countries not because the dollar is a vehicle and reserve currency, but because the United States is so large and because its own monetary policy is seldom influenced by external considerations. Even if the United States had financed its deficits entirely with SDRs (assuming it had had enough of them), the surplus countries would have had a problem in preventing unwanted monetary expansion at home. The ability of the United States to incur overall deficits without running out of reserves did give it some extra freedom in pursuing domestic policies. (That freedom, incidentally, was bolstered by U.S. capital controls. As Cooper argues, controls permitted the United States to run a more autonomous monetary policy without overly antagonizing other countries.) Whether the United States derived other significant advantages from the ability to run deficits is less clear. The paper properly disposes of the seignorage issue. I have always believed that the economic advantages to the United States, apart from freedom for monetary policy, were relatively minor. And since the asymmetry is a political irritant to other countries, this country stood to lose little economically and to gain something politically by agreeing to a more symmetrical system. 
The entire C-20 reform negotiation can be summarized as an effort by other countries to end the so-called "exorbitant privilege" of the United States to run "deficits without tears," while the United States held that it could take this step only with assurances of an effective adjustment process that would make a convertibility commitment possible. The major question therefore is whether the United States will continue to be an international money creator. This is the asymmetry that bothers the rest of the world, for both political and economic reasons.

Throughout the reform exercise, no one expressed a wish to replace the dollar in its leading role as a private asset, and it is likely to continue long in that role; but that is of little importance, as I have tried to suggest. What international harmony, political and economic, requires is a system in which the United States is subject to constraints in its capacity to flood the world with reserves. ${ }^{1}$ In exchange for this, it should demand, and has demanded, a strengthened adjustment process in which it is not required to be passive or to precipitate an international crisis in order to bring about a change in its effective exchange rate. That important degree of symmetry should be attainable.

This whole question is now complicated by the tendency of oil exporters to accumulate assets in the form of dollars. These accumulating claims should be regarded not as reserves, but as long-term capital outflows from OPEC countries and as long-term capital inflows to the United States insofar as they come here. Another complication is whether the new system will be one of managed floating rather than of par values. In my view, the difference between managed floating under international surveillance and truly adjustable par values is minor.

Finally, I do not understand the assertion in the last paragraph of the paper that "consistency in external targets is unlikely if the United States does not assume some special responsibility" for the system. Does this mean U.S. passivity? That would be a return to the status quo ante. Or does it mean an active role for the United States, the largest country, in the attempt to agree in the IMF and the OECD on a set of consistent targets and on policies to achieve them? The latter approach seems to me to be the course that is called for by economic and political realities.

1. Although the United States had this potential for the entire period from the end of World War II until 1973, the average annual increase in foreign official dollar holdings was quite moderate until 1970. 


\section{General Discussion}

Several of the discussants sought to distinguish more sharply a number of issues about the role of the United States in international finance: the private use of the dollar as an international vehicle currency, its official use as a reserve asset, the $n$ th-country role for the United States in international payments, and U.S. leadership in world financial decisions. William Poole discussed the use of the dollar as a world currency for private transactions, and saw that as its most important special function. Weir Brown noted that the $n$ th-country role for the United States was primarily a passive arrangement, quite separate from the need for U.S. economic and financial leadership among nations. Similarly, widespread holdings of dollars abroad do not necessarily add to U.S. power, according to Frank Schiff. That depends, he suggested, on where the decisionmaking power lies on the accumulation and disposition of the holdings. In principle, the currency held could be the American dollar while the decisionmaking mechanism could be multilateral. In fact, said Stephen Magee, the United States had given away power in the form of political favors before the devaluation to induce foreign central banks to hold on to their dollars. While she was willing to view these as separate issues, Marina Whitman doubted that they were independent of each other.

In connection with private demands for dollars, William Gibson pointed out that the asset certainty of dollar-denominated securities is dependent upon the stability of interest rates as well as the stability of exchange rates and the price level. He observed that the variability of U.S. interest rates has risen along with the variability of inflation rates.

Magee thought that the discussion of the world role of the dollar should be organized as a cost-benefit analysis of the various functions. Presumably there is a net world gain from the key currency role if the alternatives to the dollar are less efficient. Whitman said people have had, and still do have, a preference for the dollar as world money, from which she inferred a perceived efficiency advantage for the dollar in comparison with any available alternatives. Magee and William Branson were generally concerned about the impressionistic concepts of "symmetry," "leadership," and the like. Branson thought these (as well as "openness" and "interdependence") could be constructively formalized in a model that specified their meaning in terms of key parameters. 
Franco Modigliani warned that the burden of the oil-induced trade deficits could be maldistributed around the world unless the decisions are carefully coordinated. The disposition of OPEC capital exports should not be allowed to determine the trade deficits. Instead, all countries should agree upon target trade deficits, with the size of the oil deficit of each country as a first-approximation target for its trade deficit. Such a decision would avoid shifting resources temporarily into export industries during the energy squeeze. Branson suggested that the United States could stand a larger share of the total trade deficit without encountering the protectionist reactions Cooper had mentioned if its economy were expanding rather than contracting. Cooper reiterated his expectation that some industrial countries would not be willing to incur large and prolonged debts and thus would not accept their share of the trade deficit. Hence, even in an expanding economy, the United States could not accept a completely passive role.

More generally, Hendrik Houthakker argued that national policy objectives may include particular targets for trade, foreign investment, and the like, rather than mere overall payments equilibrium. The emerging trade deficit of the United States in 1969-71 generated protectionist pressures that contributed to the devaluation of the dollar and the end of the Bretton Woods system. The United States has gradually eliminated tariffs and it has no export duties. The main instrument for influencing the trade account is thus the exchange rate, but changes in it may at times affect direct investment, other capital accounts, and nontrade items in the current account in undesirable ways. Houthakker thought the United States should have the option of imposing export duties. But his main point was to stress the variety of "real" consequences of changing the exchange rate, some of which tend to be blurred in a financially oriented study like Marina Whitman's paper. 